\section{ВХОЖДЕНИЕ ТУВЫ B СОСТАВ СССР: АЛЬТЕРНАТИВНЫЕ МНЕНИЯ}

\section{Иванна В. Отрощенко}

Институт востоковедения им. А. Е. Крымского

Национальной академии наук Украины,

Украина

\section{TUVA'S ACCESSION TO THE USSR: ALTERNATIVE OPINIONS}

\author{
Ivanna V. Otroshchenko \\ A. Yu. Krymskyi Institute of Oriental \\ Studies, National Academy \\ of Sciences of Ukraine, \\ Ukraine
}

Включение Тувы в состав СССР в 1944 г. стало последним крупным территориальным приобретением Советского Союза, неординарным событием, многие детали которого до сих пор остаются неизвестными. У исследователей остается много вопросов относительно причин, инициаторов и обстоятельств этого события. Российские исследователи пишут про предопределенность такого объединения, отмечая и имевшие место нарушения, например, отсутствие референдума по указанному вопросу. В статье же анализируются некоторые из тенденций научного освещения этого процесса в историографии других стран в сопоставлении с оценками российских ученых.

Западные исследователи обсуждали много нюансов, так, встречается утверждение, что в 19442. Тува была аннексирована СССР. Достаточно распространены аналогии между тувинской ситуацией и присоединением к СССР стран Балтии. При этом авторы размышляли: почему Советский Союз решился на такое присоединение, тогда как, помимо Тувы, были и другие претенденты на объединение с Москвой, например, МНР и Синьцзян.

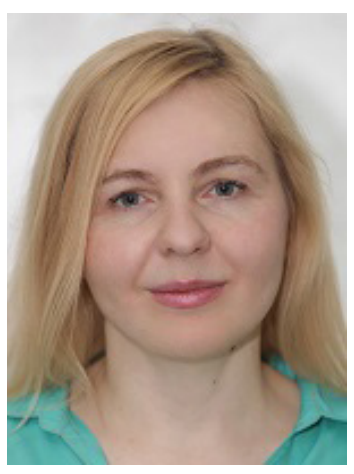

Tuva's accession to the USSR in 1944 was the Soviet Union's last large territorial acquisition. Many details of this extraordinary event are still unknown. Many questions concerning its reasons, initiators and circumstances still remain unanswered. Russian researchers highlight the predictability of the event, although they note the accession was violating international norms - e. g., in the absence of a referendum. This article looks at some of the trends in historiographic discussion of the accession process in Russia and elsewhere.

Western scholars focus on many of the nuances. It is not uncommon to read that in 1944 Tuva was annexed by the USSR. Analogies are drawn between the accession of Tuva and the Baltic states. The question Western authors poise is why the USSR focused on Tuva when other claimants for accession were also available, such as Mongolian People's Republic and Xinjiang. The most detailed

Отрощенко Иванна Витальевна - доктор исторических наук, ведущий научный сотрудник Отдела Дальнего Востока Института востоковедения им. А. Е. Крымского Национальной академии наук Украины; главный редактор журнала «Східний світ» («Мир Востока»). Адрес: 01001, Украина, г. Киев, ул. Грушевского, д. 4, к. 226. Эл. адрес: shidnyj.svit@gmail.com

Otroshchenko Ivanna Vitalievna, Doctor of History, Leading Research Fellow, Department of the Far East, A. Yu. Krymsky Institute of Oriental Studies, National Academy of Sciences, Republic of Ukraine; Editor-in-Chief, Shìdnij svìt (Mir Vostoka). Postal address: Apt. 226, 4 Grushevsky St., 01001 Kyiv, Ukraine. Email: shidnyj.svit@gmail.com 
Наиболее структурировано и емко соображения о причинах присоединения Тувы к СССР изложены британским советологом В. Коларием в 1950-х г2.

По мнению автора, вхождение Тувы в состав СССР не было детерминировано. Советская политика в отношении бывшего российского протектората прошла определенную эволюцию: на протяжении ряда лет рассматривались разные варианты развития событий. В целом, сыграла свою роль историческая память: сталинская политика к середине XX в. все больше возвращалась к имперским внешнеполитическим приоритетам (Тува в 1914 2. стала протекторатом царской России); Внешняя Монголия и Синьцзян ценились как элементы буферного пояса по российской границе (Тува же граничила с дружественной МНР); обнаружение в Туве урана могло стать еще одним аргументом в глазах советского руководства в пользу присоединения Тувы к Советскому Союзу.

Наличие большого числа версий и предположений вокруг истории присоединения Тувы к СССР свидетельствует и о том, насколько мало нам попрежнему известно об этом событии.

Ключевые слова: Тува; история Тувы; Тувинская Народная Республика; вхождение в СССР; СССР; С. К. Тока; И. В. Сталин; западная историография; зарубежное тувиноведение; международные отношения; Китай; Монголия; Синьзян; дискуссии; референдум; тувинцы; уран; природные ресурсы and concise argument on why Tuva acceded to the USSR was developed by British Sovietologist W. Kolarz in the 1950s.

The author of this article held that, unlike the prevalent opinion, the accession of Tuva was not predetermined, and the Soviet policy towards its ex-protectorate did evolve. Over a number of years, several options had been discussed, but the final outcome was informed by historical memory. By mid-20th century, Stalinist foreign policy tended to drift towards imperial priorities of the past: in 1914, Tuva became an imperial protectorate, while the Outer Mongolia and Xinjiang were seen as buffer territories along the Russian border. Tuva was not such a buffer: it was located between the USSR and the Moscow-friendly Mongolian People's Republic. The discovery of uranium deposits in the region could have been seen by the Soviet leadership as another argument in favor of accepting Tuva as a member of the USSR.

The proliferation of versions of Tuva's accession to the Soviet Union is in itself a proof of how little we know so far about this significant historical event.

Keywords: Tuva; history of Tuva; Tuvan People's Republic; accession to USSR; USSR; S. K. Toka; I. V. Stalin; Western historiography; Tuvan studies outside Russia; international relations; China; Mongolia; Xingjiang; debates; referendum; Tuvans; uranium; natural resources

\section{Введение}

Включение Тувы в состав СССР стало последним крупным территориальным приобретением Советского Союза, неординарным событием, многие детали которого до сих пор остаются неизвестными. Начиная с 1990-х гг. появился ряд научных публикаций, в которых проясняются некоторые нюансы этого процесса, даются те или иные оценки (Alatalu, 1992: 881-882, 887-890; Mongush, 1993: 47-52; Хомушку, 2002: 15-18; Москаленко, 2004: 159-168; Саая, Сат, 2006: 276-283; История Тувы, 2007: 389-394; Харунова, 2011: 50-59; Байыр-оол, 2014, Электронный ресурс и др.). Тем не менее, у исследователей остается много вопросов и предположений относительно причин, инициаторов и обстоятельств превращения Тувинской Народной Республики в Тувинскую автономную область РСФСР.

Для российских исследователей характерны использование аргументов про неизбежность, предопределенность такого объединения («Урянхайский край всегда исторически тяготел к России») и т. п. Автор ставит перед собой цель про- 
анализировать некоторые из тенденций освещения этого процесса в историографии других стран в сопоставлении с оценками российских ученых. В статье рассматриваются главным образом научные публикации; анализ политического дискурса и медиатекстов не входит в задание настоящего исследования, хотя они также представляют значительный интерес и являются свидетельством резонанса события, произошедшего более 70 лет назад и продолжающего оставаться предметом рефлексии и аргументом в полемике и сегодня.

\section{Объединительный процесс: хронология, мотивы и обстоятельства}

По словам историка Н. П. Москаленко, архивные документы свидетельствуют о том, что инициатива о вступлении Тувы в состав СССР исходила от тувинской правящей верхушки (в частности, от генсека С. Токи) причем дважды - в 1939 г. и в апреле 1941 г. (Москаленко, 2004: 162). По ее мнению, Тува ощущала определенные трудности в получении экономической помощи от СССР, поэтому изменение статуса ТНР, как полагали ее руководители, могло существенно улучшить социально-экономическое положение республики.

Другая российская исследовательница Ю. Ч. Хомушку полагает, что необходимость вступления ТНР в состав СССР определялась сложной международной обстановкой на Дальнем Востоке. Тувинское руководство рассматривало этот шаг как средство обеспечения государственной безопасности в условиях нарастающей внешней агрессии и дополнительный ресурс для экономического, политического и культурного развития, а руководство СССР - как возможность обеспечения безопасности на советско-китайской границе (Хомушку, 2002: 17-18).

«B тех конкретно-исторических условиях Тува не имела иного выбора, который обеспечил бы ей более правильный и легкий путь поступательного развития», - пишется в коллективной монографии ведущих ученых-историковтувиноведов «Истории Тувы» (История Тувы, 2007: 394).

Из приведенных оценок в целом вырисовывается мотивация тувинской правящей элиты в этом вопросе.

Об инициативе 1939 г. известно мало (см.: Alatalu, 1992: 888). Ее особо не освещают и не комментируют. Известно, что 26 апреля 1941 г. Политбюро ЦК ТНРП отправило в Москву прошение о принятии Тувы в состав СССР («вероятно по указанию ВКП(б)», - добавляют некоторые исследователи (Саая, Сат, 2006: 277)); под обращением стояли подписи Токи и всех членов политбюро ЦК ТНРП: Базыр-Сата, Мандараа, Баира, Анчимы, Чимбы (Байыр-оол, 2014, Электронный ресурс). Среди российских авторов распространено мнение, что нападение Германии на Советский Союз приостановило решение вопроса. Н. Москаленко полагает, что в те годы политическая ситуация на Дальнем Востоке, а также неудачная война с Финляндией, резко снизившая международный авто- 
ритет СССР, делали нежелательным положительное решение данного вопроса (Москаленко, 2004: 162).

Несмотря на то, что весной 1941 г. решение вопроса о присоединении Тувы было, как минимум, отложено, обращает на себя внимание характерная риторика в отношении СССР, присутствующая в более поздних тувинских государственных документах. Например, в Постановлении ЦК ТНРП и Совета министров ТНР о дополнительном наборе лошадей для отправки в подарок Красной армии от 3.11.1941 г. встречаем следующую фразу: «Посылка героической Красной Армии такого количества лошадей является выполнением нашего священного долга перед нашей родиной - СССР...» (Российский государственный архив социально-политической истории, дальше - РГАСПИ. Ф. 495, оп. 153, ед. хр. 76, л. 149 об.).

Встречаются и замысловатые формулировки. Так, в Постановлении ЦК ТНРП о задачах трудящихся женщин в отечественной войне советского народа от 18.09.1941 г., в частности, говорится: «Тувинские женщины от глубины души любят наше отечество - великий СССР и его родного брата ТНР...» (РГАСПИ. Ф. 495, оп. 153, ед. хр. 76, л. 99). Еще в одном документе «О текущем моменте Отечественной войны и задачах ТНРП. Доклад товарища Тока на V пленуме ЦК ТНРП от 31.10.1942 г.» читаем: «За истекший период еще более укрепилась дружба между нашим Отечеством - СССР и нашей страной» (РГАСПИ. Ф. 495, оп. 153, ед. хр. 78, л. 49).

Судя по формулировкам «наша родина - СССР», «наше Отечество - СССР» в документах ЦК ТНРП и Совета министров Тувы начала 1940-х гг., похоже, тувинское руководство считало гипотетическое объединение свершившимся фактом: остается только гадать, получили ли они какие-то обнадеживающие сигналы от советских правителей во время обращения 1941 г. или просто считали нужным при каждом удобном случае демонстрировать свою абсолютную лояльность советской стороне в тяжелые военные годы. Привлекает внимание и тот факт, что в Постановлении Совета министров ТНР и ЦК ТНРП от 8 сентября 1943 г. «О переводе тувинской письменности с латинизированного на русский алфавит» говорится: «Во исполнение решения XII съезда ТНРП, указавшего на необходимость перевода тувинской национальной письменности с латинизированного на русский алфавит, “в целях дальнейшего развития национальной культуры и приближения ее к социалистической культуре народов СССР...” (Сборник законов ..., 1944: 437). Еще в Постановлении ЦК ТНРП и Совета министров ТНР об улучшении материально-бытового и культурного положения хошунных работников от 7 мая 1941 г., в частности, значилось: в целях поднятия политических и иных знаний хошунных работников, изучения русского языка и письменности поручить Отделу культурно-массовой и просветительной работы ЦК ТНРП организовать при хошкомах партии библиотеки литературы на русском языке (РГАСПИ. Ф. 495, оп. 153, ед. хр. 75, л. 135). 
23 ноября 1943 г. на Каирской конференции, во время беседы двух президентов - Т. Рузвельта и Чан Кайши, среди обсуждаемых тем был вопрос о Внешней Монголии и Танну-Туве. Президент Рузвельт поинтересовался, в частности, нынешним статусом Танну-Тувы и ее историческими отношениями со своими соседями. Чан Кайши отметил, что этот район является неотъемлемой частью китайской Внешней Монголии, пока он не был насильственно забран и аннексирован Россией. Он сказал, что вопрос о Танну-Туве, а также о Внешней Монголии, должен быть урегулирован вовремя, чтобы пройти переговоры с Советской Россией (Foreign Relations of the United States, 1961: 325). Некоторые исследователи обосновано предполагают, что этот интерес американской стороны к тувинскому вопросу мог побудить советское руководство не откладывать его решение до конца войны (см.: Саая, Сат, 2006: 281).

Исходя из записей самого С. Токи, 17 июня 1944 г. произошла встреча тувинской делегации во главе с ним и наркома иностранных дел В. Молотова, и на этой встрече тувинский генсек в очередной раз декларировал желание ТНР вступить в состав Советского Союза. В ходе беседы В. Молотов сказал: «Во время войны даже удобнее разрешать такие вопросы. Если 2-3 года (назад), то есть в начале войны, эти вопросы были неясны, то теперь вопрос ясный, и поэтому мы обсудим» (цит. по: Байыр-оол, 2014: Электр. ресурс и др.).

26 июня 1944 г. ЦК ТНРП и правительство ТНР в очередной раз направило обращение с вопросом о присоединении в ЦК ВКП(б) на имя В. Молотова и секретаря ЦК ВКП(б) Г. Маленкова, из которого становятся известны интересные детали: «Еще в 1941 г. Политбюро ЦК ТНРП официальным письмом возбудило ходатайство о принятии ТНР в состав Советского Союза. В 1943 г. эта просьба в беседе с Вами, товарищ Молотов, возобновлялась. Но вопрос этот по обстоятельствам внешнеполитического характера был отложен... Дальнейшее более успешное развитие ТНР может быть осуществлено только в составе СССР, а потому просим принять ТНР в состав СССР на правах автономной области Красноярского края. Если по каким-либо причинам Вы сочтете присоединение ТНР к СССР в настоящее время нецелесообразным, просим утвердить следующие мероприятия переходного характера, которые подготовят все необходимые условия для вхождения в подходящий момент ТНР в состав СССР» (цит. по: Харунова 2011:52). Чрезвычайный и Полномочный Посланник СССР в ТНР А. К. Тюрин и советник ЦК ТНРП Я. К. Калиничев прокомментировали вышеупомянутое обращение как правильное и своевременное (там же: 52).

Тувинские власти «направляли запросы на вступление в Советский Союз в 1939, 1941 и 1943 гг., но большинство наблюдателей считают, что инициатива исходила от Сталина», - пишут западные исследователи Ли Нарангоа и Р. Крибб (Narangoa, Cribb, 2014: 189). Тут следует напомнить, что в 1923-1953 гг. политику СССР, РКП(б) - ВКП(б) - КПСС и Коминтерна в отношении Китая определял главным образом И. Сталин, который, считая себя лучшим советским специ- 
алистом по Китаю, действовал по собственному усмотрению и не приглашал других советских руководителей или экспертов к участию в выработке решений по Китаю (Воскресенский, 2004: 463). Можно предположить, что и судьба Тувы, на которую Китай продолжал предъявлять свои права, решалась в первую очередь им.

В августе 1944 г. в Кызыл был направлен ответ на письмо ЦК ТНРП от 26 апреля 1941 г., в котором говорилось о согласии советского правительства рассмотреть вопрос о принятии ТНР в состав СССР (Хомушку, 2002: 16). 21 августа 1944 г. С. Тока направил письмо Г. Маленкову, где сообщил, что в соответствии с указаниями из Москвы были проведены IX пленум ЦК ТНРП и VII Чрезвычайная сессия Малого Хурала (Москаленко, 2004: 165). На пленуме обсуждался вопросы о вхождении Тувы в состав СССР, а на VII Чрезвычайной сессии Малого Хурала была принята Декларация о вхождении ТНР в состав СССР. Возглавляла Малый Хурал Х. Анчимаа, которая также являлась женой главного в тувинском руководстве инициатора присоединения Тувы к СССР - С. Токи. Как подчеркивает эстонский историк и политик Т. Алаталу: «Именно в период ее пребывания на посту судьба Тувы была окончательно решена» (Alatalu, 1992: 887).

11 октября Президиум Верховного Совета СССР принял постановление о включении Тувы в состав Советского Союза на правах автономной области. Это постановление было опубликовано 1 ноября 1944 г. только в тувинской прессе. Объявление было сделано в Кызыле на VIII чрезвычайной сессии Малого хурала 1 ноября 1944 года.

Интересно отметить роль советской прессы в «оформлении» процесса интеграции Тувы в состав СССР. Как отмечает В. Кан, исследовательница, специализирующаяся на истории тувинских средств массовой информации, в 19441945 гг. с помощью СМИ насаждалось мнение, что вхождение ТНР в состав СССР было единственным правильным решением, руководство республики тем самым исполнило заветную мечту всех аратов. Демонстрация в прессе народного волеизъявления уже принятого решения была важной. Это придавало легитимный характер новому административно-политическому устройству (Кан, 2015: 124). В августе 1946 г. американский поверенный в делах Э. Дурброу сообщал из Москвы, что советская пресса 17 августа посвятила треть своих полос прославлению советской политики в Танну-Туве в качестве примера «братской помощи великой державы маленькому народу» ((UNTITLED). August 19, 1946: 2). Пресса утверждала, что включение Танну-Тувы в СССР в 1944 году было вызвано народным запросом среди коренного населения. Э. Дурброу подчеркивал, что это первое публичное объяснение «полностью одностороннего включения этого якобы независимого государства в Советский Союз» ((UNTITLED) ... , 1946: 2, Электр. ресурс).

По мнению российского исследователя Н. В. Абаева, в 1944 г. Республика Танну-Тува присоединилась к СССР на основании свободного (по крайней мере, 
для большей части населения) волеизъявления тувинского населения (Абаев, 2006: 206). Похожей точки зрения придерживаются и другие российские исследователи. При этом признаются и амбиции Советского Союза по расширению своей территории, наблюдавшиеся в то время. Н. Москаленко полагает: судя по известной политике И. В. Сталина, осуществление которой он начал еще в конце 1930-х гг. в условиях передела карты мира, проявившегося в аннексии Советским Союзом Прибалтики, Бессарабии, Западной Украины, в попытке присоединить военным путем Финляндию, ему хотелось восстановить СССР в границах Российской империи. Единственной территорией, не присоединенной к началу войны с Германией, оставалась Тува, которая до Октябрьской революции находилась под протекторатом России, но фактически оказалась включенной в Российскую империю (Москаленко, 2004: 162; см. также: Alatalu, 2013: 99). Возможно, есть определенные основания считать, что акция присоединения Тувы все же секретно была инициирована Москвой и что интересы политической элиты ТНР и глобальные цели советского руководства могли совпасть, - справедливо отмечает историк М. Харунова (Харунова 2011: 51; см. также: Хомушку, 2002: 16).

Российские исследователи перечисляют и комментируют следующие нарушения с правовой точки зрения в процессе принятия решения о вступлении Тувы в СССР: 1) декларация «О вхождении ТНР в состав СССР» была принята Малым, а не Великим Хуралом (парламентом, который являлся высшим органом государственной власти ТНР; именно на нем лежало установление основных принципов и мероприятий внешней и внутренней политики); 2) вышеуказанное решение Сессии Малого Хурала от 17 августа 1944 г. руководители республики скрывали от своего населения несколько месяцев вплоть до ноября, когда оно появилось в прессе; 3) решение Президиума Верховного Совета СССР о приеме ТНР в состав СССР не было утверждено Верховным Советом СССР даже после войны, когда он уже начал работать.

Еще один аргумент указывают западные исследователи: при заключении советско-китайского договора 1945 г. советская сторона обязалась признать независимость Внешней Монголии, а Тува, по мнению ряда наблюдателей и китайской стороны, являлась составной частью последней.

\section{Вопрос о референдуме}

Среди одного из нарушений в процессе объединения называют и отсутствие референдума по этому судьбоносному для тувинского народа вопросу. Отдельные российские авторы отмечают: тот факт, что решение о вхождении ТНР в состав СССР не было принято путем всеобщего голосования, вызывает определенные сомнения по поводу его законности. Поскольку в аналогичной ситуации относительно суверенитета МНР был проведен плебисцит, почему со- 
ветское и тувинское правительства не захотели считаться с мнением населения Тувы остается непонятным (Саая, Сат, 2006: 279).

Тот факт, что решение о вступлении Тувы в СССР не было достигнуто путем всеобщего голосования, явно указывает на то, что это была 100\% аннексия, видимо, спланированная в Москве, - пишет М. Монгуш (Mongush, 1993: 50). Он справедливо отмечает, что сейчас трудно оценить, как проголосовало бы население Танну-Тувы. Несмотря на то, что там была влиятельная русская колония (из общей численности населения в 1944 г. около 95000 тыс. 81 тыс. были тувинцами, а остальные преимущественно русскими), экономика была далека от социализма, а частный сектор достигал 57,3\% в 1943 г. (там же). «Указом Верховного Совета Российской Советской Федеративной Социалистической Республики (РСФСР), изданным 13 октября 1944 года, Тува была аннексирована без консультации с тувинским коренным населением», - пишут западные исследователи (Alatalu, Strupp, 2012).

Полемика по этому вопросу упоминается, в частности, в «Истории Тувы» (История Тувы, 2007: 391). «Вообще, с правовой точки зрения в Туве и России следовало провести референдумы по этому вопросу. Но в конституции и других законодательных актах СССР, РСФСР и ТНР такая процедура не предусматривалась», - пишется в издании (История Тувы 2007, 391).

Тут следует заметить, что все же упоминание всенародного референдума присутствовало уже в Конституции СССР 1936 года. Так, в ст. 49 п. 9 указывалось, что «Президиум Верховного Совета СССР... г) производит всенародный опрос (референдум) по своей инициативе или по требованию одной из союзных республик» (Конституция СССР 1936 года: 11, Электр. ресурс). Этот пункт воспроизводился во всех последующих редакциях Конституции СССР 1936 г. В Конституции СССР 1977 г. и всех ее последующих редакциях значилась ст. 5: «Наиболее важные вопросы государственной жизни выносятся на всенародное обсуждение, а также ставятся на всенародное голосование (референдум)» (Конституция СССР в редакции ..., Электр. ресурс). Этой статьей воспользовались для проведения всесоюзного референдума о сохранении Советского Союза (17 марта 1991 г.). Есть упоминание о референдуме и в Конституции РСФСР 1937 г.: «Статья 33. Президиум Верховного Совета РСФСР... в) производит всенародный опрос (референдум)...» (Глава III. ... , Электр. ресурс). Действительно, советская власть не спешила прибегать к такому демократическому инструменту внутри страны, но не исключала его использование во внешнеполитической практике (см., напр.: Комарова, 2014: 58). Пример с плебисцитом в МНР - тому подтверждение. Проведение плебисцита было предложено китайской стороной, чтобы подтвердить стремление монгольского народа к независимости и как-то объяснить китайскому обществу признание Китаем этой независимости. Поскольку результат такого референдума был для советской стороны очевиден, с этим китайским предложением согласились. 
Поэтому вопрос остается: почему такое важное решение не было принято путем всеобщего голосования в Туве, если, как утверждается, действительно большинство тувинцев положительно относились к отказу от независимости и вхождению своей страны в состав СССР? Нельзя сказать, что идеи решения урянхайского (тувинского) вопроса путем плебисцита никогда не возникало. В научной литературе первые лаконичные упоминания о возможном плебисците, который решил бы судьбу Тувы, относят к 1916 г. Далее, в «Краткой записке по Урянхайскому вопросу», сохранившейся в Государственном архиве РФ среди бумаг «Омского правительства», в заключительной части мы находим следующее предложение: «...не только формальная просьба Урянхов в 1914 году, но и реальные нужды населения, сознающего необходимость поддержки более могущественного соседа (причем туземцы приглядываются, кто из трех соседей сильнее), тот факт, что симпатии большинства населения на стороне русских дают нам право отстаивать протекторат России над этим полунезависящим Краем. Эти последние соображения, вместе со страхом Урянхов перед крутым китайским режимом, дают уверенность, что в числе других мер желательным для России явился бы плебисцит, как мера наиболее согласная с принципом соопределения мелких народностей, выдвигаемых Президентом Вильсоном» (Государственный архив Российской Федерации - далее ГАРФ. Ф. 200, оп. 1, ед. хр. 501, л. 41об.). Тут нужно оговориться, что Российское (Омское) правительство (1918-1919), в частности, по причине своего неустойчивого положения было вынуждено идти на компромиссы и проводить более либеральную политическую линию в Урянхае по сравнению с жесткой политикой Российской империи.

Предложения плебисцита звучали и во времена ТНР, по-видимому, с монгольской стороны. Так, летом 1924 г. во время Хемчикского восстания Чрезвычайный и полномочный представитель СССР Я. Давтян, в переговорах со своим монгольским коллегой Х. Максарджабом, настаивал на невозможности обсуждения вопроса о судьбе Тувы, поскольку это компетенция Москвы и Урги. Советский представитель также сказал, что считает нецелесообразным какой-то «плебисцит» (к тому же, в таких крайне ненормальных условиях - в присутствии вооруженных группировок и т. д.), мол, «у нас есть ряд более объективных данных» (РГАСПИ. Ф. 495, оп. 153, ед. хр. 1, л. 19). Завуалированный намек о плебисците можно усмотреть в совместном заявлении советской и монгольской сторон, адресованном тувинскому правительству (от 15 августа 1924 г.): «Правительства Союза Советских Социалистических Республик и Монголии, отнюдь не вмешиваясь в Ваши внутренние дела, помогут Вам всегда дружескими советами и указаниями и окажут Вам всяческую культурную поддержку. В нужный момент они вынесут окончательное решение о Танну-Тувинской государственности, приняв во внимание желания самого народа. Теперь же этот вопрос нужно отложить» (Собрание архивных документов ..., 2014: 100). О том, что тувинский «вопрос может быть решен только волей самого Урянхайского народа», говорилось и на I Великом Народном Хурале Монголии (ноябрь 1924 г.) (Протоколы ..., 44 
1925: 81). В 1925 г. монгольское правительство приняло постановление о Туве. В нем упоминалось обращение 62 жителей Оюннарского сомона Тес-Хемского хошуна с просьбой объединится с единоплеменной Монголией, связанной с ними общими обычаями и верой (РГАСПИ. Ф. 495, оП. 152, ед. хр. 42, л. 71). По мнению монгольской власти, это заявление свидетельствовало о несомненных стремлениях тувинцев к объединению с Монголией. Утверждалось, что позиция местного населения была выяснена путем плебисцита ${ }^{1}$ (РГАСПИ. Ф. 495, оп. 152, ед. хр. 42, л. 72). При обсуждении тувинского вопроса на IV съезде МНРП (23.092.10.1925) монгольский министр иностранных дел С. Гиваабалжир заметил, что из 9 хошунов Урянхая 6 однозначно высказались за присоединение к Монголии, а меньшинство - за независимое существование Тувы, но этот вопрос остается нерешенным (РГАСПИ. Ф. 144, оп. 1, ед. хр. 40, л. 167).

Несмотря на подобные разговоры, плебисцит в Туве в первой половине XX в. так и не был проведен, можно предположить, потому, что как российская, так и советская власть прекрасно понимали, что результаты народного волеизъявления могут быть не в пользу интересов северного соседа. С другой стороны, отказ от проведения плебисцита в 1944 г. (как, впрочем, и отказ от вынесения судьбоносного вопроса на Великий Хурал) можно объяснить решением советского руководства, мало ценившего демократические и конституционные процедуры, сохранять запланированное присоединение в тайне.

\footnotetext{
${ }^{1}$ По словам известного американского монголиста и политолога Р. Рупена, в феврале 1925 года заместитель премьер-министра ТНР выразил желание объединить страну с Монголией, и группа тувинских чиновников подписала петицию с таким же обращением (Rupen, 1966: 45). В письме полпреда МНР Данзана советскому наркому иностранных дел Г. В. Чичерину (10.07.1925 г.) говорится: «Весною текущего года орган управления, именующий себя Советом Танну-Тувинского Народного Правительства, обратился к Министерству Иностранных Дел Правительства Монгольской Народной Республики и к Консолу Союза ССР в Танну-Тува, г. Чичаеву, с письмами за №№ 6, 14, 22 и 170, в которых излогаются многочисленные доводы, высказываемые населением хошунов Урянхая, в силу коих Танну-Тувинская Республика не может существовать, как самостоятельное государственное образование. В упомянутых письмах высказывается мысль заключающаяся, главным образом, в желании народных масс объединиться с Монголией, как с народом имеющим неразрывную связь с Танну-Тува по национальному родству и традиционным обычаям... Такое желание народных масс было одобрено Советом Танну-Тувинского Народного Правительства, Малым Хуралданом депутатов всех хошунов и Центральным Комитетом ТаннуТувинской Народной Партии, после чего в виде письменного обращения доведено до сведения Консула СССР в Урянхае, г. Чичаева, для передачи на рассмотрение Правительства СССР и одновременно доведено до сведения Министерства Иностранных дел Монголии и Центрального Комитета Монгольской Народно-Революционной Партии. Усматривая из вышеупомянутых документов незыблемость желания Танн-Тувинского народа и основываясь на решении, достигнутом... между черезвычайным уполномоченным Правительства СССР, г. Давтяном, и черезвычайным уполномоченным Правительства МНР, г. Максаржапом, заключающемся в том, что при разрешении урянхайского вопроса Правительства обоих дружественных народов будут руководиться подлинным желанием самого Тувинского народа лишь после того, как оно будет выявлено, Министерство Иностранных Дел МНР находит необходимым снестись с Правительством Союза Советских Социалистических Республик через своего Полномочного Представителя для скорейшего и окончательного разрешения выдвигаемого вопроса сообразно истенному желанию Танну-Тувинского народа» (Собрание архивных документов ..., 2014: 242-244).
} 


\section{Дискуссии об аннексии}

Во многих западных и восточных научных публикациях встречается утверждение, что в 1944 г. Тува была аннексирована СССР (Lattimore, 1946: 650, 1962: 76; Tang, 1959: 423; Rupen, 1973: 466; Henze, 1994: 79; Sullivan, 1995; Paine, 1996: 329; Batbayar, 1996: 41; Harrison, Электр. pecypc; Endicott, 1999: 63; Forsyth, 2000: 356; Stepanov, 2000: 318; Walters, 2001: 25; Somuncuoğlu, 2002: 282; Atwood, 2004: 557; Kuei-hsiang Hsu, 2007: 3; Hagendoorn, Poppe, Minescu, 2008: 355; Stépanoff, 2009: 17; Minahan, 2004: 210; 2014: 281; Rieber, 2015: 405; Rojo et al., 2016: 30 и др.)1.

По мнению американского синолога П. Тана, эта односторонняя прямая аннексия даже не соответствовала позднейшему китайско-советскому соглашению 1945 г., в котором и СССР, и Китай обязались гарантировать независимость Внешней Монголии в целом (Tang, 1959: 400). Похожей точки зрения придерживался Ф. С. Мансветов, один из видных эсеров, в свое время участвовавший в руководстве Дальневосточной республикой (1920-1922) и перебравшийся затем на Запад². Он отмечал, что, наконец, в 1945 г., под давлением США, Китай подписал договор с Советским Союзом, в котором он признавал независимость Внешней Монголии после проведенного плебисцита. В то же время советское правительство соглашалось признать независимость Монгольской Республики в ее принятых границах, включая Танну-Тувинскую республику. Следовательно, акт включения Танну-Тувы в Советский Союз не может рассматриваться как законный международный акт до тех пор, пока Китай не согласится с этим. Такая ситуация является причиной того, что Советы тайно аннексировали этот регион, - утверждал Ф. Мансветов (Mansvetov, 1947: 12). Как видно, вышеприведенная аргументация исходила из того, что западные исследователи традиционно рассматривали Туву как зависимое продолжение Внешней Монголии. Комментируя присоединение Тувы к СССР, американская исследовательница Э. Эндикотт подчеркивает, что, возможно, такое развитие событий свидетельствует о непонимании того факта, что тувинцы были, по крайней мере, частично монголами по этнической составляющей и весьма в социальном и культурном плане - частью Монголии (Endicott, 1999: 64).

Достаточно распространены среди, в первую очередь, западных исследователей, аналогии между тувинской ситуацией и присоединением к СССР стран Балтии. «Забыть Туву, вспоминая об исчезновении прибалтийских государств, кажется еще более озадачивающим, когда мы вспоминаем, что Эстония, Лат-

${ }^{1}$ B некоторых англоязычных публикациях интеграция Тувы в состав СССР определяется словом «абсорбция» («поглощение») (Ballis, 1956: 327-328; Rupen, 1975; McMullen, Электр. pecypc; Soni, 2009: Электр. ресурс и др.).

${ }^{2}$ Ф. С. Мансветов с 1931 г. жил в США, сотрудничал с Гуверовским институтом войны, мира и революции. Бывавший когда-то в Монголии Мансветов написал ряд статей о МНР. 
вия и Литва были частью Российской империи с 18-го века, а Тува находилась в российской сфере влияния только с 1912 года и сформировала часть ее с 1914 по 1921 год», - пишет Т. Алаталу (Alatalu, 1992: 881, см. также: 887). Как и в странах Балтии, эта аннексия была заключена в форме одобрения Верховным Советом заявки на вступление, - отмечает английский исследователь С. Салливан (Sullivan, 1995; см. также: McMullen, Электр. ресурс).

По словам Н. Москаленко, в конце 1980-х гг. в Туву начали приезжать эмиссары из Прибалтики, утверждавшие, что судьба Тувы и прибалтийских государств имеет много общего, что Тува вошла в состав СССР не по доброй воле, а была оккупирована советскими войсками. Подобные высказывания публиковались как в центральной, так и в региональной российской прессе (Москаленко, 2004: 160; см. также: Eismont, 1996. Электр. ресурс; McMullen, Электр. peсурс). Можно предположить, что в данном случае политический и медиа- дискурсы оказали некоторое влияние на последующее развитие научной стороны вопроса.

Некоторые авторы проводят параллели между внешней политикой Российской империи и политической линией СССР (т. н. «вторая российская аннексия» (Kolarz, 1954: 167)). Турецкий исследователь А. Сомунджуоглу отмечает, что в отличие от стран Прибалтики, аннексированных СССР во время Второй мировой войны, аннексия Тувы не привела к реакции внешнего мира. И снова, как когдато поступала царская Россия, Советский Союз делал вид, будто ничего не происходит в течение двух лет, пока 16 августа 1946 г. не было объявлено, что Тува входит в Советский Союз (Somuncuoğlu, 2002: 282). Исследователь упоминает т. н. обращения трудящихся с призывами присоединиться к СССР, использованные во время попыток Токи и его окружения включить Туву в Советский Союз ${ }^{1 .}$ А. Сомунджуоглу проводит аналогию с обращениями о подданстве тувинской знати времен царской России и полагает, что это не что иное, как действия по подготовке законной среды для аннексии (Somuncuoğlu, 2002: 281-282).

Таким образом, несмотря на заверения Чичерина в обратном ${ }^{2}$, советское правительство выполнило задачу поглощения Урянхая, поставленную царским правительством, - пишет американская исследовательница С. Пэйн, специализирующаяся на политической и военной истории Восточной Азии, в особенности Китая, в современную эпоху (Paine, 1996: 329).

\footnotetext{
${ }^{1}$ «Все прошения, ранее отправленные в Москву, были основаны на письмах, полученных якобы ЦК ТНРП от крестьян и рабочих Тувы, они выражали свое желание присоединиться к великому СССР» (Саая, Сат, 2006: 278).

${ }^{2}$ Имеется ввиду известное обращение НКИД РСФСР к тувинскому народу (от 14.09.1921), где отмечалось, что Советская Россия не рассматривает эту территорию (Урянхай) как свою и никаких видов на нее не имеет (см.: Собрание архивных документов о протекторате ..., 2014: № 133).
} 


\section{Другие претенденты на объединение с СССР}

Западные исследователи задавались вопросом, пытались объяснить присоединение ТНР к СССР. Вопрос, действительно, интересный и остающийся открытым: почему Советский Союз решился на такое присоединение? Ведь, помимо Тувы, были и другие претенденты на объединение с Москвой, но они не получили положительного ответа. Как и в Туве, такая инициатива исходила от правящих элит или отдельных их представителей. Для нас особенно интересен пример МНР и Синьцзяна - еще двух осколков Цинской империи, политики которых в этот же период (1940-е гг.) обращались с подобными предложениями к Москве.

По воспоминаниям известного советского востоковеда и дипломата М. С. Капицы, из монгольских руководителей такую идею высказал в 1944 г. член Политбюро, секретарь ЦК МНРП Ч. Сурунжаб советскому посланнику И. А. Иванову, который сразу же получил указание из Москвы: «быть весьма осторожным и никогда не давать повода для подобных разговоров» (цит. по: Капица, 1996: 193). Из архивных документов становится известно, что вопрос о присоединении МНР к СССР поднимался некоторой частью монгольского состава (особенно молодежи $)^{1}$ в годы войны после вхождения в состав СССР Тувинской Народной Республики. Премьер-министр МНР Х. Чойбалсан тогда отрицательно отнесся к этим настроениям, считая постановку вопроса о вхождении МНР в СССР преждевременной (РГАСПИ, ф. 82, оп. 2, ед. хр. 1280, л. 22).

«В то время как Тува, бывший вассал Монголии, была включена в Советский Союз, сама Монголия оставалась якобы независимой от Москвы. Причиной сдержанности русских по этому поводу стало сомнение в том, что “односторонняя советская аннексия Монголии ... могла бы сорвать ожидания Сталина о поддержке со стороны США, чтобы националистический Китай подчинился ялтинским положениям, включая признание советских прав в Маньчжурии, стратегически очень желательной для русских. Поэтому было бы глупо аннексировать Монголию, а также Туву...”», - пишет американский исследователь, профессор Дж. Форсайт, ссылаясь на статью Р. Рупена «The absorption of Tuva» (Forsyth, 2000: 357).

Вопрос о присоединении МНР к СССР новый генеральный секретарь ЦК МНРП Ю. Цэдэнбал пытался ставить перед ЦК ВКП(б) во время своего пребывания в Москве в конце 1947 г. 19 августа 1949 г. посланник СССР в МНР К. Ю. Приходов в своем докладе секретарю ЦК ВКП(б) Г. М. Маленкову писал: «еден-

\footnotetext{
${ }^{1} \mathrm{~B}$ записке «О составе и деятельности Монгольской народно-революционной партии», составленной тов. Маслениковым (от 12.03.1950 г.), в частности, сообщается следующее: «В 1944 г. в связи с принятием Тувинской народной республики в состав СССР среди некоторых работников ЦК МНРП (Цеденбал, Сурунжаб) были настроения за присоединение МНР к СССР. Цеденбал не отказался от этой идеи и в настоящее время» (РГАСПИ. Ф. 17, оп. 137, ед. хр. 410, л. 70).
} 
бал считает, что МНР уже использовала все свои внутренние возможности для развития производительных сил республики, ее культурного и политического роста и, по его мнению, МНР сейчас практически подошла к необходимости присоединения к Советскому Союзу, т. к. своими силами дальше развиваться она не в состоянии, а помощь Советского Союза МНР, как дружественному самостоятельному государству, не может быть бесконечной. Цэдэнбал оговорился, что возможно с точки зрения общей международной обстановки вопрос о присоединении МНР к Советскому Союзу является сейчас не своевременным, тем не менее в вопрос о перспективах дальнейшего развития МНР должна быть внесена какая-то ясность, т. к. должной ясности в этом вопросе у ЦК МНРП и правительства сейчас якобы нет» (РГАСПИ, ф. 82, оп. 2, ед. хр. 1280, л. 20-21). В заключение своей беседы с советским посланником Ю. Цэдэнбал сказал, что он намерен рекомендовать Х. Чойбалсану во время его пребывания в Москве попросить совета по принципиальным вопросам дальнейших перспектив развития МНР. По словам К. Приходова, Цэдэнбал считает, что Монголия вплотную подошла к необходимости вхождения в СССР, Чойбалсан, наоборот, относится к этому отрицательно. Что показательно, сам Приходов был согласен с мнением Чойбалсана (РГАСПИ, ф. 82, оп. 2, ед. хр. 1280, л. 4). Бросается в глаза сходство между приведенным в начале статьи отрывком из обращения ЦК ТНРП и правительства ТНР от 26 июня 1944 г. и речью Ю. Цэдэнбала, переданной Приходовым. Только если в первом случае, как было указано, советские представители горячо поддержали такое обращение («как правильное и своевременное»), то во втором советский посланник был настроен иначе, что, разумеется, отражало отношение советской стороны к тем или иным разговорам об объединении.

Последняя встреча Чойбалсана со Сталиным состоялась осенью 1949 г. (30 сентября - 1 октября) накануне провозглашения Китайской Народной Республики (KHР). Чойбалсана прежде всего интересовало отношение Сталина к проблеме объединения (в новых условиях) Внешней и Внутренней Монголии в одно государство (больше см.: Отрощенко, 2010). Получив отрицательный ответ от советского лидера, Чойбалсан решился поставить вопрос иначе - о возможности вступления в СССР объединенной Монголии. Сталин ответил, что этого делать не следует. Поддерживая в принципе идею объединения Внешней и Внутренней Монголии, Советский Союз хочет, чтобы это было единое самостоятельное государство, не входящее ни в состав России, ни в состав Китая (Рощин, 2005: 122; см. также: Шинкарев, 2006, 1: 74; больше об инициативах присоединения к СССР отдельных представителей монгольской правящей элиты см.: Шинкарев, 2006, 1: 78-82; Капица, 1996: 193-194; Atwood, 2004: 105, 515; Dashpurev, Usha, 1993: 38).

М. С. Капица вспоминал, что в начале 1970-х гг., когда он заведовал I Дальневосточным отделом МИД, министр иностранных дел СССР А. А. Громыко спросил: «что бы я сказал если бы возник вопрос о вхождении МНР в состав СССР. Я реагировал остро, дал категорически отрицательный ответ и привел аргумен- 
ты насчет ослабления в таком случае безопасности страны. Я так и не узнал, почему возник этот вопрос, была ли это собственная идея министра, или где-то она обсуждалась, и он хотел узнать «за» и «против» нее» (Капица 1996: 192).

В 1973 г. американский исследователь У. Хитон уже писал: «Монголия близка к Советскому Союзу, но Цэдэнбал и другие лидеры не хотят, чтобы Монголия стала еще одной Танну-Тувой» (Heaton, 1973: 250). Историк-монголист К. Этвуд полагает, что к середине 1970-х гг. сам успех монгольской индустриализации с помощью Советского Союза снизил ощутимую потребность Монголии в подобном объединении, и эта проблема потеряла свою актуальность (Atwood, 2004: 515).

Освещая «монгольский вопрос», российский китаист Ю. Галенович напоминает, что СССР попытался в максимально возможной степени воспользоваться итогами Второй мировой войны. Он добился от Китая признания независимости МНР, присоединил к себе Туву; однако он не пошел ни на включение в состав СССР МНР, ни на присоединение Внутренней Монголии к МНР, хотя такого рода поворот событий не мог исключаться. Очевидно, здесь сыграло роль соотношение сил в мире. США, другие страны Запада и Китай не позволили бы тогда Советскому Союзу осуществить эти планы (Галенович, 1992: 100, см. также: там же: 99).

Тем не менее, еще во второй половине 1940-х - начале 1950-х гг. западные исследователи, эксперты, дипломаты предполагали вероятность того, что СССР продолжит консолидацию или распространение своей власти в приграничных китайских областях. По их мнению, в частности, эти процессы могли принять форму поддержки определенной федерации, например, монголы Внешней и Внутренней Монголии, Барги, Восточного Синьцзяна с Бурят-Монгольской ACCP (Fisher, 1949: 199-200). Не исключалось также, что Синьцзян может повторить судьбу МНР, а то и Тувы (Foreign Relations of the United States ..., 1960: 1236; Foreign Relations of the United States ..., 1972: 1221).

К началу 1940-х гг. влияние Советского Союза в Синьцзяне было настолько велико, что в январе 1941 г. военный губернатор Синьцзяна Шэн Шицай (19331944) направил И. Сталину письмо, в котором предлагал «отложиться от Китая, “создать в Синьцзяне советскую республику и включить ее в состав СССР”, мотивируя это наличием “удобного случая, когда английские империалисты и Чан Кайши не могут вмешаться в дела Синьцзяна”, а Советский Синьцзян мог бы направить весь Китай на путь советизации» (Гасанлы, 2016: 108; Сыроежкин, 2003: 119). Однако советское руководство на это не пошло.

Обращение о присоединении 1941 г. было не единственным. «В июне 1944 года генерал-губернатор Шэн Шицай, поняв, что стремительно теряет власть в провинции, написал письмо Иосифу Сталину с предложением принять Синьцзян в состав СССР при единственном условии, что он будет председателем Совета народных комиссаров этой 18-й советской республики, однако получил отказ. 
Любопытно, но меньше чем через два месяца правительство Советского Союза получило аналогичную просьбу из соседней Тувы. 17 августа 1944 года чрезвычайная сессия Малого хурала Тувинской Народной Республики приняла Декларацию к Верховному Совету СССР с просьбой о принятии республики в состав Союза ССР. Эта просьба была удовлетворена, и Указом Президиума Верховного Совета РСФСР от 13 октября 1944 года бывшее суверенное тувинское государство было включено в Российскую Федерацию на правах автономной области», - пишет российский автор ряда книг о Синьцзяне В. Обухов (Обухов, 2012: 500).

Похоже, к вопросу расширения своих границ советская власть подходила предельно прагматично: радикальные пожелания зарубежных элит принимались к сведению, только если они отвечали интересам СССР, какими они виделись его правителям.

Политика СССР относительно Синьцзяна выглядит закономерным продолжением политики Российской империи относительно этого региона. Здесь и традиционные для Российской империи XIX в. опасения активности Англии в Синьцзяне, и настрой на сохранение по линии государственных границ «от Амура до Памира» так называемых буферных государств (Lattimore, 1930: 326327). Когда-то на телеграмме Н. Пржевальского, в которой утверждалось, что Китайский Туркестан готов подняться против Пекина, Александр III написал: «Я сомневаюсь в пользе этого присоединения» (цит. по: Схиммельпеннинк ван дер Ойе, 1997: 220). Такие сомнения оставались и у советских правителей.

Таким образом, как кажется, в вопросе Синьцзяна советская власть в целом придерживалась принципа сохранения территориальной целостности Китая. Как полагает российский китаист Ю. Галенович, Сталин и Чан Кайши с самого начала взаимоотношений между ними были заинтересованы, чтобы Синьцзян оставался хоть и отдаленной, но частью Китая, чтобы силы третьих стран не получили возможности преимущественного влияния на ситуацию в этой провинции (Галенович, 2008: 222). В то же время азербайджанский историк и общественно-политический деятель Дж. Гасанлы считает, что, несмотря на торжественные заявления Сталина об уважении территориальной целостности Китая, сделанные им как во время обсуждений между союзниками, так и во время встреч с китайскими официальными лицами, секретные документы указывают на его намерения оторвать Синьцзян от Китая, по крайней мере о включении под советский контроль северных районов провинции, богатых природными ресурсами (Гасанлы, 2016: 338).

Вопрос о природных ресурсах немаловажен для заявленной тематики, так как заинтересованность в них прослеживается в политике СССР 1940-х гг. на восточном направлении, в частности по отношению к Синьцзяну, Ирану и Туве. «Если интересы Советов в отношении Турции заключались в образовании дружественного правительства, овладении выходом к ближневосточным энергетическим ресурсам и установлении совместного контроля над проливами, то 
в отношении северного Ирана и западного Китая добавились экономические нужды Москвы на нефть и другие природные ресурсы... В Синьцзяне, кроме нефти советские интересы касались также и олова, вольфрама, берилла, урана и других полезных ископаемых и цветных металлов. В военный и послевоенный периоды Советский Союз хотел удовлетворить свои потребности в ценных металлах за счет Восточного Туркестана», - пишет Дж. Гасанлы (там же: 335).

В начале холодной войны западные эксперты уделяли особое внимание сведениям о советских научных экспедициях, в частности тех, которые работали в МНР, Туве, «неофициальных экспедициях в Синьцзян или Маньчжурию», от которых, в частности, ожидалась информация об обнаружении урана, вольфрама, тория, иридия, алюминия, нефти, молибдена, марганца, свинца и т. д. (Academy of Science's Role..., 1949: 4-6, Электр. pесурс). В. Обухов на страницах своих книг рассказывает об советских геологических экспедициях в Синьцзян, в частности в рамках советского атомного проекта и поисков урана (напр.: Обухов, 2012: 490495). Тува, как и Синьцзян, владела богатым запасом полезных ископаемых, в частности, месторождениями урана, что также могло сказаться на ее судьбе.

\section{Почему Тува? Причины включения Тувы в состав СССР}

Наиболее структурировано и емко соображения по этому поводу (насколько известно автору) изложил британский советолог В. Коларц в своей книге «Тhе Peoples of the Soviet Far East» (Нью-Йорк, 1954). По его словам, причины, вызвавшие вторую российскую аннексию Тувы, можно резюмировать следующим образом.

Во-первых, Тува была очень богата крупным рогатым скотом. Для советской власти представлялось желательным довести страну до советской плановой экономики. «Скот Тувы имел особое значение для России во время войны: в русско-японской войне 1905 года, в Гражданской войне и в “Великой Отечественной войне” 1941-45» (Kolarz, 1954: 167). Только в последней войне Тува поставила 40000 своих лучших лошадей ${ }^{1}$ и 600000 голов крупного рогатого скота, - писал исследователь. К слову, уже 23 июня 1941 г. на заседании Политбюро ЦК ТНРП постановили, в частности, мобилизовать в помощь Красной Армии СССР не менее 5000 лошадей (РГАСПИ. Ф. 495, оп. 153, ед. хр. 75, л. 181).

Во-вторых, полагал В. Коларц, Тува образует национальную крепость, охраняющую подступы к Кузбасу (Кузнецкому угольному бассейну), одному из основных угледобывающих и металлургических центров Советского Союза. Было бы предпочтительнее иметь эту крепость внутри Советского Союза, чем предоставить ей даже фиктивный суверенитет (Kolarz, 1954: 167; cм. также: Tang, 1959: 401-402).

\footnotetext{
${ }^{1}$ Судя по данным современных исследователей, цифра поставленных лошадей была значительно больше, достигая 50000 (Хомушку, 2002: 15).
} 
Третьим, и, возможно, самым важным моментом В. Коларц называл тот факт, что Тува имеет крупные месторождения металлов и минералов, в том числе золото (эксплуатируемое трестом «Тувзолото»), платину и даже уран ${ }^{1}$. Решение России об аннексии Тувы, несомненно, было основано, прежде всего, на долгосрочных стратегических соображениях, но наличие полезных ископаемых, включая уголь, медь, кобальт, ртуть, свинец, цинк, золото и асбест, придало ему значительную экономическую ценность, - справедливо отмечает Дж. Форсайт (Forsyth, 2000: 356). Может ли быть совпадением, что Тува с ее урановыми месторождениями была присоединена к Советскому Союзу в то время, когда атомные исследования в западном полушарии шли к своей кульминации, - риторически вопрошал В. Коларц (Kolarz, 1954: 168; см. также: Körner-Lakatos, 2010: 335).

В подобных предположениях британский исследователь был не одинок. Например, Ф. С. Мансветов в своей статье, посвященной Туве, отмечал следующее. До взрывов в Хиросиме и Нагасаки советские источники неизменно указывали на наличие крупных месторождений урана в Туве, как правило, в связи с другими радиоактивными элементами. Однако с тех пор все упоминания об уране прекратились (Mansvetov, 1947: 9). Добавим, что в рапортах, статьях и экспертных оценках тех лет, сохранившихся в архивах американских спецслужб, можно встретить ряд упоминаний о Туве именно в «атомном» контексте. Там говорится, в частности, о «первом атомном заводе СССР в Танну Туве (советский Атомград, построенный в пустынных районах между Сибирью и Монголией)» (The atomic bomb potential... 1951: 2, Электр. ресурс); «Нет сомнения, что Республика Танну Тува является вторым советским “Атомградом” (Information on Soviet military..., 1950: 4, Электр. ресурс). В одном из рапортов его автор писал, что в 1942 г. СССР уже подготовил область Танну-Тува «для использования тяжелой военной промышленности» (там же). «В 1942 году на железнодорожной станции Иркутск я заметил множество транспортов под охраной НКВД, идущих в сторону советской Монголии. Я получил следующую конкретную информацию о том, что транспорт несет: 1) демонтированные части заводского и лабораторного оборудования... 3) все транспорты были на пути в Танну-Туву... и 5) политзаключенный, работавший на границе с Танну Тувой, сказал мне, что НКВД отправил всех политических заключенных на Камчатку, и только отдельные заключенные, срок которых не превышал трех лет, остались в этом районе» (там же: 4-5). Автор документа подчеркивал, что Танну-Тува тщательно охраняется при участии специальных контрразведчиков МВД и МГБ.

В-четвертых, продолжал В. Коларц, тувинцы тесно связаны с некоторыми тюркскими народами, проживающими в самой Советской России, на западе и севере бывшей тувинско-советской границы. Эти народы - ойроты, шорцы и хакасы. С точки зрения алтайских националистов, в частности, не было при-

1 «Маленькая Танну-Тува, расположенная между Южной Сибирью и Северо-Западной Монголией, богатая природными ресурсами, включая уран...» (Yakobson, 1949: 188). 
чин, по которым эти народы должны принадлежать Российской империи, а не объединяться с тувинцами в независимое государство ${ }^{1}$. Пока существовала независимая Тува, всегда существовала возможность того, что ойроты и хакасы будут тяготеть к этой стране. И по этой причине было бы безопаснее иметь Туву в составе СССР (Kolarz, 1954: 168). Исследователь также отмечает, что тувинские коммунисты, следуя советской политике подчеркивания тюркских элементов тувинской культуры ${ }^{2}$, акцентировали на своих этнических связях с Алтаем и Хакассией при лоббировании слияния с СССР³ (Kolarz, 1954: 168; Fondahl, 1995: 24).

Такое предположение отсылает нас к интересному вопросу идей об объединении тюрков Южной Сибири (главным образом, алтайцев и хакасов, в отдельных случаях и тувинцев) в одной республике, имевших место в первой трети ХХ в.

Из публикации В. Н. Тугужековой мы узнаем, в частности, что в марте 1925 г. на втором уездном съезде Советов председатель уездного ревкома Г. И. Итыгин выступил с докладом об объединении Ойротии (Ойратской АО), Хакасии и Тувы в Тюркскую Советскую Социалистическую Федеративную Республику. Съезд принял резолюцию: «...такое объединение будет своевременным и необходимым для нас как родственных народностей» и поручил уездному исполкому начать по этому вопросу переговоры с Ойротией и тувинским правительством и известить об этом ВЦИК через Сибирком и Губисполком и теперь

\footnotetext{
${ }^{1}$ Судя по некоторым публикациям, алтайские лидеры еще во второй половине 1910-х гг. видели себя во главе будущего независимого Алтая, или Ойротского государства, которое должно было быть сформировано совместно с частью Минусинского района, населенной тем же этническим фондом, и с Урянхаем, «который позже, под Советами, стал Танну-Тувинской республикой» (Varneck, 1943: 80). Однако этот план получил поддержку только от его промоутеров в Алтайской Горной думе и поэтому не стал осязаемым политическим проектом. Российские исследователи рассказывают об идее алтайских националистов во главе с художником Г. Чорос-Гуркиным создать государство Ойрат, цитируя протокол учредительного съезда Горно-Алтайского краевого съезда инородческих и крестьянских депутатов 21 февраля 1918 г.: «В силу права на самоопределение народностей, созданного великой русской революцией и съезд признал за благо объединить в самостоятельную республику земли входящие некогда в состав государства Ойрат, а именно: Русский Алтай, земли Минусинских туземцев, Урянхай, Монгольский Алтай и Джунгарию» в составе Общероссийской федерации (Тюхтенева, 2006: 166). Сам Г. Чорос-Гуркин в начале 1920-х гг. оказался в Туве, где пробыл до 1925 г.

2 По мнению исследователей, национальная политика Москвы и во второй половине ХХ в. была преимущественно направлена на подавление проявлений панмонголизма и тувинского национализма. Пропаганда и образование продолжали приуменьшать монгольские связи Тувы и подчеркивать тюркские влияния (Anaiban, Walker, 1996: 181-182).

${ }^{3}$ В дневнике, где описано вхождение ТНР в состав СССР, написанном С. Токой и названном «Воссоединение», есть рассказ о приеме у В. М. Молотова 17 июня 1944 г. Судя по записям, в своей речи, обращенной к Молотову, тувинский правитель мотивировал обращение о «воссоединении», в частности, следующим аргументом: «Опыт показывает, что родственные народы (Хакасии, Ойротии) в составе СССР на много лет ушли вперед в хозяйственном и культурном строительстве. В этих районах народ, который не так давно еще кочевал, теперь работает и живет оседло, построили заводы, дороги, школы и больницы, материально и духовно живут много лучше нашего... В промышленном развитии успехов почти нет, так как нужно все создавать заново. Например, хакасы и ойроты имеют большие успехи в этом деле лишь потому, что они входят в общий план великого социалистического строительства СССР» (цит. по: Байыр-оол, 2014: Электр. ресурс).
} 
же начать подготовительную работу по созданию Тюркской ССР (Тугужекова, 2016: 22). Свой доклад о создании новой республики Г. И. Итыгин выслал в Ойратскую АО. Однако партийные органы Енисейской и Алтайской губерний и Сибирского края решительно отвергли это предложение как несовместимое с принципами национальной политики Советской власти (там же: 22).

Но, похоже, такие инициативы не были забыты. Так. 9 октября 1929 г. заместитель наркома иностранных дел СССР Л. Карахан в обращении к коминтерновцам утверждал, что «наша задача, мне кажется, состоит в том, чтобы тувинцы могли при нашей помощи создать свою письменность на основе латинизированного тюркского алфавита, что они уже начали делать и что их культурно может сблизить с алтайцами и хакасами» (подчеркнуто в источнике. - И. О.) (РГАСПИ. Ф. 508, оп. 3, ед. хр. 5, л. 125). Как видно, идея о Тюркской ССР была ему знакома и окончательно подобные замыслы высокопоставленный дипломат не отбрасывал.

Разумеется, перечисленные соображения о причинах включения Тувы в состав СССР являются далеко не единственными. По мнению известного российского историка-международника С. Лузянина, на конец 1942 г. в Москве уже сформировалось решение о включении Тувы в состав Советского Союза на правах областной автономии. Последнее обстоятельство подкреплялось ходатайством тувинского руководства о желании войти в состав СССР (Лузянин, 2003: 249). Исследователь полагает, что «причины вхождения Тувы в состав СССР в 1944 г. носят комплексный характер и связаны не только с ситуацией в монголо-тувинских отношениях в 20-40-е годы. Урянхайский край всегда исторически тяготел к России. В 1914 г. он вошел под ее официальный протекторат. В 20-е годы, когда международно-политическая ситуация с Внешней Монголией была неясной и существовала опасность, что она станет частью Китая, самостоятельная Тува была бы выгодным для Советской России “буфером” между ней и Китаем. В 30-40-е годы, когда международная обстановка вокруг МНР кардинально изменилась и исчезла опасность ее присоединения к Китаю, а также возросла роль Советского Союза, контролировавшего ситуацию, Тува во многом потеряла для него свое значение. К тому же экономически Тувинский край был более интегрирован в структуру народного хозяйства Алтая и Юго-Восточной Сибири, чем Монголия, сохранявшая свою хозяйственную самобытность. Пограничные раздоры МНР и Тувы в условиях военного времени ускорили решение Москвы о вхождении Тувы в состав СССР» (Лузянин, 2003: 262-263).

В Интернет-проекте «The World at War» подчеркивается, что в течение 1943 г. режим Чан Кайши расшатывал позиции России в Синьцзяне. И аннексия Танну-Тувы трактуется как предупреждение Сталина Китаю не отстаивать свои претензии на советский сателлит Монголию (Tannu Tuva ..., Электр. ресурс; см. также: McMullen, Электр. ресурс). Однако тут же подчеркивается, что первые советские месторождения урана были обнаружены в Тану-Туве в 
1944 г. Предположение о связи между событиями в Синьцзяне и присоединением Тувы к СССР принадлежало известному американскому советологу Адаму Уламу ${ }^{1}$. Если Улам прав, то просьба Тувы о включении, вероятно, была организована просоветским элементом в Кызыле для дальнейшего восприятия сталинских геостратегических целей по отношению к Китаю, как и страны Балтии были принуждены присоединиться к СССР как буфер против угроз с запада, - пишет Р. МакМаллен (McMullen, Электр. ресурс).

Еще в одной публикации, посвященной председателю Президиума Малого Хурала - Х. Анчимаа, подчеркивается, что тувинская ориентация на Москву усилилась во время войны вместе с кириллицей, заменившей латинский алфавит, русификацией социально-экономических практик и практически полным искоренением оппозиции сталинской политике. Эти тенденции достигли кульминации в 1944 г. в петиции, организованной Токой и Анчимаа, для аннексии республики. Советы, желающие получить минеральные ресурсы республики и навсегда прекратить монголо-китайские геополитические интриги вокруг региона, поддержали такую просьбу, и тувинское государство официально прекратило свое существование в ноябре 1944 г. (Khertek Anchimaa-Toka, Электр. peсурс²).

Трудно сказать, почему тувинский вопрос снова был включен в повестку дня в августе 1944 г., пишет Т. Алаталу. По его мнению, возможно, на это повлияло развитие военных действий в Китае. После японского наступления в апрелеиюне 1944 г. стало ясно, что Китай ничего не может этому противопоставить, а в Европе спала волна войны. Москва снова подняла тувинский вопрос и ответила на призыв, прозвучавший тремя годами ранее (Alatalu, 1992: 888).

Иногда советское решение о присоединении Тувы объясняют в частности, намерением добиться абсолютной лояльности тувинского народа. Так, Т. Алаталу пишет, что открытое сопротивление промосковскому курсу в Туве продолжалось до 1941 г, и, возможно, включение Тувы в СССР было направлено, среди прочего, на подавление антисоциалистического сопротивления навсегда (там же: 887). Еще один исследователь также видит в этом процессе средство устранения политической оппозиции в стране и предотвращения возможных претензий Китая на восстановление контроля над Тувой в конце Второй мировой войны (Christopher, 2001: 55).

Встречались в западных публикациях и объяснения, исходившие из ограниченного потенциала ТНР. Так, ее включение в советские границы называли одним из плодов победы и добавляли, что население Тувы слишком мало,

\footnotetext{
${ }^{1}$ Имеется ввиду издание: Adam B. Ulam. Expansion and Coexistence; Soviet Foreign Policy 1917-73. NY: Praeger, 1974. В 1943 г. в Урумчи открылось Генеральное консульство США. В то же время имел место отзыв большинства советских дипломатических и торговых представительств в СССР весной 1943 г. Осенью того же года советские войска, находящиеся в Хами, были выведены с территории Синьцзяна в СССР.

${ }^{2}$ Указанная статья также размещена в английской Википедии.
} 
чтобы существовать как независимая республика (Grajdanzev, 1945: 337). Выдающийся исследователь Внутренней Азии О. Латтимор полагал: эта аннексия может рассматриваться как продолжение китайского признания независимости Монголии. Пока Китай подчеркивал свой суверенитет над Внешней Монголией, китайская точка зрения заключалась в том, что Танну-Тува была частью Внешней Монголии, а русская аннексия серьезно помешала бы российско-китайским отношениям. Поскольку сама Внешняя Монголия не претендует на суверенитет над Танну-Тувой и поскольку тувинский народ находится на уровне развития, аналогичном некоторым «фрагментарным» народам под советской юрисдикцией, его существование как полностью суверенного государства было очень искусственным («Since Outer Mongolia itself does not claim sovereignty over Tannu-Tuva, and since its people are at a level of development... similar to that of several "fragmentary" peoples under Soviet jurisdiction, its existence as a fully sovereign state was highly artificial») (Lattimore, 1946: 650).

\section{Альтернативные сценарии}

По нашему мнению, вхождение Тувы в состав СССР не было детерминировано. Советская политика в отношении бывшего российского протектората прошла определенную эволюцию. Начнем с того, что Урянхай не был присоединен к Советской России (СССР), к примеру, в первой половине 1920-х гг. как другие протектораты Российской империи - Хивинское ханство и Бухарский эмират. Да и само внезапное образование Народной Республики Танну-Тувы в 1921 г., как мы считаем, не было реализацией политической линии Москвы или Сиббюро ЦК РКП(б) (больше см.: Отрощенко, 2011: 118-133).

На протяжении ряда лет рассматривались разные варианты развития событий. Особенно хорошо это иллюстрируют отдельные документы, где советские дипломаты излагают свое виденье тувинского вопроса.

Выше уже шла речь о дискуссиях советского и монгольского представителей в ходе завершения Хемчикского восстания 1924 г. Я. Давтян, подводя итоги своей работы в Туве, полагал, что присоединение Тувы к Монголии Советскому Союзу политически невыгодно, поскольку избавит последнего соответствующего влияния, а также резко ухудшит положение 12 тысяч русских (якобы русским в Монголии живется гораздо хуже). При этом положение русских в Туве, по словам самого Давтяна, было значительно лучше, чем положение соответствующего сегмента в Советском Союзе (РГАСПИ. Ф. 495, оп. 153, ед. хр. 1, л. 14). Поэтому желательно оставить статус-кво. Отметим, что об исторических претензиях северного соседа на Туву речь не идет. При этом записи Давтяна свидетельствуют, что он не исключал вероятности присоединения Тувы к Монголии в перспективе. В конце 1920-х годов советский полпред в Туве А. Старков отмечал, что «ориентация СССР была на объединение Тувы с Монголией на фе- 
деративных началах. Это подчеркнуто и в переговорах по поводу Кемчугских событий» (РГАСПИ. Ф. 495, оп. 153, ед. хр. 37, л. 10).

В августе 1925 г. нарком иностранных дел Г. В. Чичерин излагал П. Никифорову, новому советскому полпреду в Монголии (1925-1927), основные положения внешнеполитической позиции СССР. Одно из них было следующим: «Урянхай мы считаем отдельной автономной Народной республикой, пребывающей под протекторатом Китая, как и Монголия. Поэтому мы возражаем против объединения Урянхая с Монголией» (РГАСПИ. Ф. 144, оп. 1, ед. хр. 7, л. 3).

Возможно, активные намерения монгольской элиты восстановить «Великую Монголию», с новой силой вспыхнувшие в 1925-1928 гг., повлияли на советскую позицию в тувинском вопросе. Сыграло свою роль и формирование т. н. правого уклона в монгольском руководстве, также беспокоившее советскую сторону. Все это прибавилось к стремлению сохранить советское доминирование в Туве.

С другой стороны, по мнению ряда исследователей, Кремль мешал вассальным державам становиться экономически или политически слишком сильными и независимыми, стремясь удержать их в сфере своего влияния. По этой причине он всегда блокировал все тенденции к территориальному расширению своих сателлитов, также как и тенденции к слишком близким связям между ними. Как пример Д. Томашич, автор ряда публикаций в области социологии международных отношений, вышедших на Западе, приводил тот факт, что в своих отношениях с Внешней Монголией Советский Союз должен был блокировать тенденции к союзу Монголии с Тувой и Внутренней Монголией, запрещая эти усилия как «панмонгольские» и «реакционные». По его словам, эта политика «разделяй и властвуй», использованная Москвой во Внешней Монголии, была повторена два десятилетия тому на Балканах ${ }^{1}$, когда Советский Союз столкнулся с перспективой Южнославянской федерации, состоящей из Югославии, Болгарии, Македонии, и, возможно, Албании и Греции (Tomasic, 1950: 39; см. также: Галенович, 1992: 99). Этот план также был осужден Кремлем как националистический и придушен прежде, чем были предприняты какие-либо важные шаги для его осуществления.

Таким образом, постепенно в тувинском вопросе акцент переходит на «самостоятельную республику». 1 февраля 1929 г. В. Мачавариани в своем докладе «Положение в тувинской Республике», адресованном П. Мифу², писал следующее: «В договоре 1924 г. с Китаем, мы оговорили, что Туву также как и Монголию считаем одной из частей китайской территории, но оставляем за собой право самостоятельной политики по отношению к этим республикам до установления

${ }^{1}$ По мнению китайского ученого Ло Сяохоя, на Востоке в 1920-1940-х гг. СССР опробовал систему, которую он потом использовал применительно к государствам Восточной Европы, объявившим о своем стремлении к социализму, а также к появившимся после Второй мировой войны таким же государствам в Азии (Галенович, 1992: 99).

${ }^{2}$ П. Миф в 1928-1935 гг. был заместителем заведующего Восточным секретариатом Исполнительного комитета Коммунистического интернационала (ИККИ). 
нормального положения внутри Китая. Отсюда политика СССР должна была заключаться в том, чтобы ко времени «нормализации» Китая, если таковая когданибудь наступит, противопоставить ей самостоятельную экономически, политически и культурно окрепшую республику, которая сама будет заявлять о своих правах» (РГАСПИ. Ф. 495, оп. 153, ед. хр. 35, л. 2). Предназначение Тувы советской дипломатией виделось и в следующем. 31 декабря 1930 г. полномочный представитель СССР в Туве Н. В. Попов писал секретарю ЦК ВКП(б) П. П. Постышеву: «Тува для нас представляет интерес по моему в том отношении, что она является нечто вроде опытного поля; опыт проделываемой нами работы по некапиталистическому пути развития народного хозяйства мы будем применять к другим восточным, колониальным и полуколониальным странам. Республика маленькая, с удивительно даровитыми и восприимчивыми способностями населения к усвоению социалистических начал. Все капитальные вложения, которые может дать СССР - окупят себя с лихвой. С большими перспективами развития сельского хозяйства (во всех его видах) животноводство, с переработкой Сельхозсырья, пушное дело, природные богатства и благоприятные климатические условия» (ГАРФ. Ф. Р-5446, оп. 12а, ед. хр. 980, л. 9).

Со временем можно было отметить уже некоторую дифференциацию, наметившуюся в восприятии советского руководства между двумя народными республиками. Так, 9 июля 1934 г. нарком иностранных дел М. М. Литвинов написал И. В. Сталину: «По нашему договору с Китаем мы признаем суверенитет Китая над Монголией и потому Монголия должна была бы быть окрашена на карте в одинаковый цвет с Китаем, а между тем ей дана совершенно особая окраска.... Я просил бы утвердить следующие инструкции, даваемые в этой области НКИД. Манчжурия и Монголия окрашиваются одинаковой краской, что и Китай, но получают особую штриховку, указывающую на несколько отличное положение этих провинций от остального Китая. Что касается Тибета, СиньЦзяна и Сов. Китая, то, поскольку ни они не объявляли своей независимости и ни одно другое государство этой независимости официально не признало, то их следует окрашивать краской Китая без штриховки. С другой стороны Тана-Тува получает особую окраску, как независимое государство» (Советское руководство ..., 1999: 292-293). 25 июля 1934 г. Политбюро рассмотрело вопрос о географических картах и по существу вопроса «о политическом закрашивании» Маньчжурии, Тибета, Синьцзяна и Тувы приняло предложение Литвинова (там же: 293). Складывается впечатление, что в этот период на суверенитете Китая над Тувой советская дипломатия уже не акцентировала, в отличие от МНР, и даже готова была позиционировать ТНР как независимое государство.

Тут следует заметить, что уже тогда надежды С. К. Токи на объединение Тувы с СССР не были тайной для советского руководства; скорее всего, озвучивал их тувинский генсек неоднократно. Например, сохранилось его обращение в Восточный Секретариат ИККИ. В начале документа стояла дата «10.IX.1934 г.», писал его С. К. Тока, судя по подписи, во время своего пребывания в Москве. «В практи- 
ческой работе в Туве встречается целый ряд непонятных вопросов, на которые прошу секретариат ИККИ дать подробное разъяснение. Это следующие вопросы: 1) Прошу дать точное разъяснение о современном положении национальной революции; “Почему Тува и Монголия являются самостоятельными Республиками, а не входя в состав Советского Союза”? - Такие вопросы часто задают араты. Как на это отвечать ${ }^{1}{ }^{\prime}$ (РГАСПИ. Ф. 495, оП. 153, ед. хр. 7, л. 3).

Пояснение, что подобный вопрос волновал тувинских аратов, вызывает сомнение. Но вот что примечательно: в конце 1920-х годов монгольские левые (1928-1932), такие как О. Бадрах и Л. Лааган (оба - западные монголы), возмущаясь халхаским доминированием в МНР, предлагали, чтобы Западная Монголия и Тува вместе присоединились к Советскому Союзу (Atwood, 2004: 515). Именно с приходом к власти левых в МНР связан некоторый период активизации монголо-тувинских отношений, инициированный монгольской стороной. Интересно, обсуждали ли монголы с тувинской стороной подобные «объединительные» замыслы, знал ли о них С. К. Тока и не они ли впервые подали ему идею о присоединении Тувы к СССР. Известно, к примеру, что летом 1930 г. в Улан-Баторе Тока беседовал с секретарем ЦК МНРП, дербетом Бадрахом (Собрание архивных документов ..., 2014: 322), которому приписывали различные амбициозные замыслы и Тува в них играла определенную роль.

То, что вышеприведенные планы казались не столь уж невероятными, показывает дальнейшее развитие событий. 12 декабря 1935 г. в Москву прибыла большая монгольская делегация во главе с премьер-министром и военным министром, которую ожидал демонстративный прием на железнодорожной станции высокопоставленными советскими военными и гражданскими официальными лицами (Foreign Relations of the United States ..., 1953: 490). И тут обращает на себя внимание чуть более поздняя запись беседы заведующего 3-м западным отделом НКИД СССР А. Ф. Неймана с временным поверенным в делах США в СССР Л. Гендерсоном о положении на Дальнем Востоке (от 14.12.1935). Гендерсон начал с того, что приезд представителей монгольского правительства вызвал целый ряд слухов. Один из них - это то, что наряду с представителями Монгольской Народной Республики в Москве находятся сейчас также делегации Тувинской Народной Республики и монгольских областей СССР и что сейчас в Москве обсуждается вопрос о создании Монгольской ССР, которая обратилась бы к Советскому Союзу с просьбой о принятии ее в состав Союза. Гендерсон добавил, что он не имеет никаких оснований считать эти слухи правильными, но просто рассказывает то, что слышал. Советский дипломат ответил, что такой слух представляет собой просто нелепость, что он основан только на чьих-то спекулятивных догадках. МНР имеет развитые и оживленные отношения с СССР, и у ее правительства, естественно, возникают от времени до времени потребности обменяться мнениями по разнообразным текущим вопросам с различными наркоматами Советского Союза (Документ № 238 ..., Электр. ресурс).

\footnotetext{
${ }^{1}$ Последний вопрос, единственный во всем тексте, был подчеркнут карандашом.
} 
Излагая ситуацию в своем докладе госсекретарю, Л. Гендерсон писал следующее: китайский посол не смог точно определить, что делает монгольская миссия в Москве (Foreign Relations of the United States ..., 1953: 489). Однако он был уверен, что ведутся переговоры о том, что в случае нападения МНР получит помощь от Советского Союза. Советник посольства Японии, в свою очередь, отмечал, что, по прибытии монгольской миссии, в Москве имели место совещания лидеров «всех важных монгольских племен» как Советского Союза, так и Внешней Монголии, включая Танну-Туву (там же: 490). Японский дипломат предположил, что эти совещания могут иметь один из следующих результатов: во-первых, заявление Монголии и Танну-Тувы о желании стать республикой в составе Советского Союза или, во-вторых, заключение оборонного союза между Советским Союзом и Монголией против агрессии с Востока. Указывалось, что высокопоставленные военные официальные лица настаивают на том, что визит носит обычный характер, аналогичный тому, который имел место в прошлом году. Л. Гендерсон отмечал: аннексия советским правительством того, что мир по-прежнему считает частью Китая, или принятие обязательств, которые ограничивали бы возможности СССР в маневрировании на Дальнем Востоке, стали бы неожиданным поворотом в наблюдавшейся ранее политике (Foreign Relations of the United States ..., 1953: 490).

Сложно сказать, насколько такие слухи были обоснованы, обдумывало ли действительно советское руководство создание Монгольской ССР. Как известно, в январе 1936 г. советское правительство приняло решение оказать МНР помощь вооружением, снаряжением и транспортными средствами, а в марте 1936 г. в Улан-Баторе был подписан советско-монгольский протокол о взаимной помощи. Возможно, слухи о Монгольской ССР были отвлекающим маневром, дымовой завесой, за которой скрывалась действительно актуальная, «военная» повестка дня. Во всяком случае, в условиях напряженной ситуации на Дальнем Востоке в 1930-е гг. иностранные наблюдатели, похоже, ожидали самых невероятных вариантов решения судьбы монгольского мира.

Существование ТНР как суверенного государства подавалось в выгодном свете и в начале 1940-х гг. Так, во время беседы первого заместителя народного комиссара иностранных дел СССР А. Я. Вышинского с посланником Чехословакии в СССР 3. Фирлингером 21 августа 1941 г. последний подчеркнул, что в настоящее время в Советском Союзе высоко поднята идея общеславянского объединения. Чехословаки приветствуют эту идею, а сам Фирлингер подчеркнул, что он считает неизбежным в будущем придать этому объединению какую-то государственную форму. Ведь не обязательно же, добавил Фирлингер, всем государствам, стремящимся к государственному объединению с Советским Союзом, вступать в союз в качестве союзной республики. Он считает, что возможны и другие формы государственного сближения. Чешскому дипломату ответили, что имеются различные государственные формы такого объединения. В Совет- 
ский Союз, например, не входят Монгольская Народная Республика и Тувинская Народная Республика, но отношения у них с СССР весьма близкие (Документы внешней политики ..., 2000: 249).

\section{Заключение}

Решение в 1944 г. тувинского вопроса стало своего рода прецедентом: в УланБаторе оно породило некоторую дискуссию среди правящей элиты о путях дальнейшего развития страны, и, насколько можно судить из западной научной литературы и экспертных оценок того времени, долгие годы виделось одним из вариантов дальнейшей судьбы МНР, а также некоторое время и Синьцзяна.

Размышляя, почему Монгольская Народная Республика и провинция Синьцзян избегли такой участи, помимо всех вышеприведенных аргументов, можно предположить следующее.

Во-первых, сыграла свою роль историческая память: сталинская политика к середине XX в. все больше возвращалась к имперским внешнеполитическим приоритетам, а Российская империя все же не видела ни Внешнюю Монголию, ни Синьцзян в своем составе. В то же время Тува в 1910-е гг. была фактически инкорпорирована в состав Российской империи.

Во-вторых, Внешняя Монголия и Синьцзян ценились как российской, так и советской дипломатией и правящей элитой в значительной степени как элементы буферного пояса по российской границе. У Тувы же отсутствовал статус буфера, поскольку она располагалась между Советским Союзом и дружественной ему Монгольской Народной Республикой.

B-третьих, обнаружение в Туве урана, отведение ей, предположительно, определенной роли в советском военно-промышленном комплексе могло стать еще одним аргументом в глазах советского руководства в пользу присоединения Тувы к Советскому Союзу.

Обращает на себя внимание тот факт, что многие исследователи, анализируя заявленную проблему, прибегают к аргументам, опирающимся на расстановку сил в мире и на Дальнем Востоке в первой половине 1940-х гг. В то же время аргумент о заинтересованности советской стороны в полезных ископаемых ТНР и добыче урана звучит главным образом от западных исследователей. Достаточно распространены среди западных исследователей и аналогии между тувинской историей и присоединением к СССР стран Балтии, а также параллели между царской и советской политикой в урянхайском вопросе.

Наличие большого числа версий и предположений вокруг истории присоединения Тувы к СССР свидетельствует и о том, насколько мало нам по-прежнему 
известно об этом событии - элементе интересного и сложного исторического периода, когда определялось послевоенное устройство мира и решались судьбы стран и народов. Широкая историографическая база, включающая исследования представителей разных стран и исторических школ, помогает составить по возможности разностороннее представление об неоднозначном и резонансном событии как советской истории, так и истории стран Востока, по крайней мере, до введения в научный оборот документов, проливающих свет на истинные мотивы советской власти, которыми она руководствовалась, планируя это присоединение, и все обстоятельства этого процесса.

\section{СПИСОК ЛИТЕРАТУРЫ}

Абаев, Н. В. (2006) Некоторые геополитические и этноисторические аспекты “урянхайской проблемы” // Этносоциальные процессы в Сибири. Тематический сборник. Вып. 7. Новосибирск : СО РАН. С. 201-206.

Байыр-оол М. С. (2014) Хроника вхождения Тувы в состав СССР [Электронный ресурс] // Тувинская правда. 25 сентября. URL: http://tuvapravda.ru/?q=content/ vossoedinenie (дата обращения: 27.08.2017).

Воскресенский, А. Д. (2004) Китай и Россия в Евразии. Историческая динамика политических взаимовлияний. М. : Муравей. 600 с.

Галенович, Ю. М. (1992) «Белые пятна» и «болевые точки» в истории советско-китайских отношений. Т. І. От Октября 1917 г. до октября 1949 г. М.: Институт Дальнего Востока. 169 с.

Галенович, Ю. М. (2008) Два генералиссимуса: И. В. Сталин и Цзян Чжунчжэн (Чан Кайши). М. : ИДВ РАН. 372 с.

Гасанлы, Дж. П. (2016) Синьцзян в орбите советской политики: Сталин и мусульманское движение в Восточном Туркестане (1931-1949) / пер. с азерб. Ф. Гаджиева. 2-е изд., стер. М. : ФЛИНТА. 360 с.

Глава III. Высшие органы государственной власти Российской Советской Федеративной Социалистической Республики / Конституция РСФСР 1937 г. [Электронный ресурс] // Электронный музей конституционной истории России. URL: http://www.rusconstitution.ru/library/constitution/articles/940/ (дата обращения: 21.08.2017).

Документ № 238. Запись беседы заведующего 3-м западным отделом НКИД СССР А.Ф. Неймана с временным поверенным в делах США в СССР Л. Гендерсоном о положении на Дальнем Востоке, 14.12.1935 / Советско-американские отношения. 1934-1939 [Электронный ресурс] // Интернет-проект «Архив Александра Н. Яковлева». URL: http://www.alexanderyakovlev.org/fond/issues-doc/70521 (дата обращения: 27.07.2017). 
Документы внешней политики. 22 июня 1941 - 1 января 1942 (2000). М.: Международные отношения. T. XXIV. 632 с.

История Тувы (2007) / под ред. В. А. Ламина. Новосибирск : Наука. Т. II. 430 с.

Кан, В. С. (2015) Этапы становления и развития периодической печати Тувы (1924-1985) // Вестник Омского университета. История. № 2. С. 121-125.

Капица, М. С. (1996) На разных параллелях. Записки дипломата. М. : Книга и бизнес. 480 с.

Комарова, В. В. (2014) Народные голосования в Российской Федерации. М.: Directmedia. $477 \mathrm{c}$.

Конституция СССР 1936 года [Электронный ресурс] // Электронный музей конституционной истории России. URL: http://www.rusconstitution.ru/library/ constitution/articles/1223/ (дата обращения: 21.08.2017).

Конституция СССР в редакции от 7 октября 1977 г. [Электронный ресурс] // Электронный музей конституционной истории России. URL: http:// www.rusconstitution.ru/library/constitution/articles/9681/ (дата обращения: 21.08.2017).

Лузянин, С. Г. (2003) Россия - Монголия - Китай в первой половине XX века. Политические взаимоотношения в 1911-1946 гг. М. : ОГНИ. 320 с.

Москаленко, Н. П. (2004) Этнополитическая история Тувы в ХХ веке. М. : Наука. 222 с.

Обухов, В. Г. (2012) Потерянное Беловодье. История Русского Синьцзяна. М. : ЗАО Издательство Центрполиграф. 676 с.

Отрощенко, І. В. (2010) “...Він живе цією ідеєю”: панмонгольський вектор Х. Чойбалсана // Східний світ. № 3. С. 81-91. (На укр. яз.).

Отрощенко, І. В. (2011) На шляху до Великої Монголії (панмонгольський рух у 1920-1930-ті роки). Київ. 456 с. (На укр. яз.).

Протоколы 1-го Великого Хуралдана Монгольской Народной Республики (1925) Улан-Батор-Хото. 276 с.

Рощин, С. К. (2005) Маршал Монголии Х. Чойбалсан. Штрихи биографии. М. : ИВ РАН. 158 с.

Саая, С. В., Сат, С. Ч. (2006) Геополитический статус Тувы в первой половине ХХ века (1911-1944 годы). Абакан : Хакасское кн. изд-во. 293 с.

Сборник законов и основных постановлений Правительства Тувинской Народной Республики (1944) / под общ. ред. Х. Анчима и С. Т. Чимба. Кызыл : Тувинское государственное издательство. 456 с.

Собрание архивных документов о протекторате России над Урянхайским краем - Тувой: к 100-летию исторического события (2014) / сост.: Бондаренко Т. А. и др. Кызыл : ТИГИ. 479 с.

Собрание архивных документов по истории Тувы (2014) : в 4-х т. Улаанбаатар; Кызыл : АДМОН ПРИНТ. Т. ІІІ. 1921-1944 гг. 418 с. 64 
Советское руководство. Переписка. 1928-1941 гг. (1999) М. : Российская политическая энциклопедия. 519 с.

Схиммельпеннинк, ван дер Ойе Д. (1997) Неизвестный Пржевальский // Ариаварта. Научный журнал. № 1. С. 207-226.

Сыроежкин, К. Л. (2003) Мифы и реальность этнического сепаратизма в Китае и безопасность Центральной Азии. Алматы : Дайк-Пресс. 736 с.

Тугужекова, В. Н. (2016) Хакасско-алтайские взаимоотношения (вторая половина XVII - начало XX в.) // Алтай - Россия: через века в будущее : материалы Всероссийской научно-практической конференции с международным участием, посвященной 260-летию добровольного вхождения алтайского народа в состав Российского государства и 25-летию образования Республики Алтай / отв. ред. В. Г. Бабин. Горно-Алтайск : РИО ГАГУ. Т. І. 444 с. С. 20-23.

Тюхтенева, С. П. (2006) Исторические и этногенетические связи монголов и алтайцев или Чингисхан возвращается // IX Международный конгресс монголоведов (Улан-Батор, 8-12 августа 2006 г.). Доклады российских ученых. М. : ИВ РAH. С. $163-168$.

Харунова, М. М. (2011) Социально-политическое развитие Тувы в середине XX века. Новосибирск : Наука. 135 с.

Хомушку, Ю. Ч. (2002) Процессы сближения и вхождения Тувинской Народной Республики в состав СССР: 20-40-е годы ХХ в. : автореф. дис.... к. ист. н. М. $18 \mathrm{c}$.

Шинкарев, Л. И. (2006) Цеденбал и его время: в 2 т. М. : Собрание. Т. 1: Любовь. Власть. Трагедия. 496 с.

Academy of Science's Role in Field Expeditions. December 29, 1949. Document Number(FOIA)/ESDN(CREST):CIA-RDP80-00926A001800040002-8 [Электронный pecypc] // CIA. Freedom of Information Act Electronic Reading Room. URL: https:// www.cia.gov/library/readingroom/docs/CIA-RDP80-00926A001800040002-8.pdf (дата обращения: 27.08.2017).

Alatalu, T. (1992) Tuva. A State Reawakens // Soviet Studies. Vol.44. № 5. P. 881-895.

Alatalu, T., Strupp, M. (2012) Tuva // Max Planck Encyclopedia of Public International Law [MPEPIL]. Vol. 10. Oxford : Oxford University Press, lk. P. 124-127.

Alatalu, T. (2013) Geopolitics Taking the Signature from the Russian-Estonian Border Treaty (2005) // Baltic Journal of European Studies Tallinn University of Technology. Vol. 3, No. 2 (14). P. 96-119.

Anaiban, Z. V., Walker, E. W (1996) On the Problem of Interethnic Conflict: The Republic of Tuva // Ethnic Conflict in the Post-Soviet World: Case Studies and Analysis. N. Y. : M. E. Sharpe. P. 179-194.

Atwood, Ch. P. (2004) Encyclopedia of Mongolia and the Mongol empire. N. Y.: Facts on File. 678 p. 
Ballis, W. B. (1956) The Political Evolution of a Soviet Satellite: The Mongolian People’s Republic // The Western Political Quarterly. June. Vol. 9, No. 2. P. 293-328.

Batbayar, Ts. (1996) Modern Mongolia a concise History. Uaanbaatar. 127 p.

Christopher, A. J. (2001) State failure in the twentieth century // Geographica Slovenica. № 34. P. 49-63.

Dashpurev, D., Usha, P. (1993) Mongolia: Revolution and Independence. 19111992. New Delhi : Subhash. 148 p.

Eismont, M. (1996) Tuva: Rejoining the Fold / Translated by Mark Eckert [Электронный ресурс] // Prism. Vol. 2, Issue 18. URL: https://jamestown.org/program/ tuva-rejoining-the-fold/ (дата обращения: 12.08.2017).

Endicott, E. (1999) Russian Merchants in Mongolia: The 1910 Moscow Trade Expedition // Mongolia in the Twentieth Century: Landlocked Cosmopolitan. N. Y.; L. : M. E. Sharpe. P. 59-68.

Fisher, H. H. (1949) Soviet Policies in Asia // Annals of the American Academy of Political and Social Science. Vol. 263: The Soviet Union Since World War II. P. 188-201.

Fondahl, G. A. (1995) Siberia's First Nations / The National Council for Soviet and East European Research. Washington. 39 p.

Foreign Relations of the United States: Diplomatic Papers, 1935. Vol. III: The Far East (1953). Editors: J. G. Reid, L. E. Gates, R. R. Goodwin. Washington : Government Printing Office. 868 p.

Foreign Relations of the United States: Diplomatic Papers. The Conferences at Cairo and Tehran, 1943 (1961). Editors: W. M. Franklin, W. Gerber. Washington : Government Printing Office. $932 \mathrm{p}$.

Foreign Relations of the United States: Diplomatic Papers. The Conference of Berlin (The Potsdam Conference), 1945 (1960) Vol. II. Editor: Richardson Dougall. Washington, Government Printing Office.

Foreign Relations of the United States, 1946, The Far East: China (1972) Vol. X. Editors: Ralph R. Goodwin, Herbert A. Fine, Francis C. Prescott, Velma H. Cassidy. Washington, Government Printing Office.

Forsyth, J. (2000) A History of the Peoples of Siberia: Russia's North Asian Colony 1581-1990. Cambridge, UK : Cambridge University Press. 476 p.

Grajdanzev, A. J. (1945) Soviet Position in the Far East // Far Eastern Survey, Vol. 14, No. 23. P. 334-337.

Hagendoorn, L., Poppe, E., Minescu, A. (2008) Support for Separatism in Ethnic Republics of the Russian Federation // Europe-Asia Studies. Vol. 60, No. 3, P. 353-373.

Harrison, K. D. Naming Practices and Ethnic Identity in Tuva [Электронный ресурс] // Swarthmore College. URL: http://www.swarthmore.edu/SocSci/dharris2/HarrisonCLS\%28corrected\%29.pdf (дата обращения: 29.07.2017).

Heaton, W. (1973) Mongolia: Troubled Satellite// Asian Survey. Vol. 13, N. 2. P. 246-251. 
Henze, P. B. (1994) Ethnic Dynamics and Dilemmas of the Russian Republic // Studies in Conflict \& Terrorism. Vol. 17, Issue 1. P. 61-86.

Information on Soviet military strength. 17 July 1950. Document Number (FOIA) / ESDN (CREST): CIA-RDP82-00039R000100070017-6 [Электронный ресурс] // CIA. Freedom of Information Act Electronic Reading Room. URL: https://www.cia.gov/ library/readingroom/docs/CIA-RDP82-00039R000100070017-6.pdf (дата обращения: 25.08.2017).

Khertek Anchimaa-Toka [Электронный ресурс] // Revolvy. URL: https://www. revolvy.com/main/index.php?s=Khertek\%20Anchimaa-Toka \&item_type=topic (дата обращения: 25.08.2017).

Kolarz, W. (1954) The Peoples of the Soviet Far East. N. Y. : Parager. 193 p.

Körner-Lakatos, E. (2010) Ada Kaleh, Tannu-Tuwa, Acre. Fünfzig historische Nischen. Monsenstein und Vannerdat, Münster.

Kuei-hsiang Hsu (2007) The Relationship between the Republic of Tuva and the Russian Federal Government since the 1990s // Bimonthly Journal on Mongolian and Tibetan Current Situation. Vol. 17, No. 1. P. 1-22.

Lattimore, O. (1930) Political Conditions in Mongolia and Chinese Turkestan // Annals of the American Academy of Political and Social Science. Vol. 152: China. P. 318-327.

Lattimore, O. (1946) The Outer Mongolian Horizon // Foreign Affairs. Vol. 24, No. 4. P. $648-660$.

Lattimore, O. (1962) Nomads and Commissars. Mongolia Revisited. London, New York : Oxford University Press. 238 p.

Mansvetov, F. S. (1947) Tannu-Tuva - The Soviet «Atom City»? // Russian Review. Vol. 6, № 2. P. 9-19.

McMullen, R. Tuva: Russia's Tibet or the Next Lithuania? [Электронный pecypc] // Friends of Tuva. URL: http://www.fotuva.org/misc/mcmullen.html (дата обращения: 20.08.2017).

Minahan, J. (2004) The former Soviet Union's diverse peoples: a reference sourcebook. Santa Barbara, Calif. [u.a.] : ABC-Clio. 389 p.

Minahan, J.(2014) Ethnic Groups of North, East, and Central Asia: An Encyclopedia. Santa Barbara, Calif. : ABC-Clio. 345 p.

Mongush, M. (1993) The annexation of Tannu-Tuva and the formation of the Tuvinskaya ASSR // Nationalities Papers: The Journal of Nationalism and Ethnicity. Vol. XXI. № 2. P. 47-52.

Narangoa, L., Cribb, R. (2014) Historical atlas of northeast Asia, 1590-2010: Korea, Manchuria, Mongolia, Eastern Siberia. New York : Columbia University Press. 352 p.

Paine, S. C. M. (1996) Imperial Rivals: China, Russia, and Their Disputed Frontier. M. E. Sharpe. 417 p. 
Rieber, A. J. (2015) Stalin and the Struggle for Supremacy in Eurasia. Cambridge University Press. 429 p.

Rojo, M., Chondan, R. M., Chondan, Ch. S., Lavrillier, A. (2016) «Adaptation des rites «traditionnels» chez les Touvas de Kyzyl de la période soviétique à l'urbanisation» [Электронный ресурс] // Études mongoles et sibériennes, centrasiatiques et tibétaines [En ligne], 47 | 2016, mis en ligne le 21 décembre 2016, consulté le 17 février 2017. URL: http://emscat.revues.org/2856 (дата обращения: 20.08.2017).

Rupen R. (1966) The Mongolian People's Republic. Stanford, Calif., Hoover Institution on War, Revolution, and Peace, Stanford University. 74 p.

Rupen, R. A. (1973) The Fiftieth Anniversary of the Mongolian People's Republic: 1921-1971 // Asian Survey. Vol. 13. No. 5. P. 458-469.

Rupen, R. A. (1975) The absorption of Tuva // The Anatomy of Communist Takeovers / Ed. Thomas T. Hammond. New Haven : Yale University Press. P. 148-150.

Somuncuoğlu, A. (2002) Tuva (Tıva) Cumhuriyeti // Türkler. Vol. 20. Türk dünyası. Yeni Türkiye Yayınları. Ankara. P. 275-295. (На турец. яз.).

Soni, Sh. K. (2009) Exploring the history of Tuva-Mongolia linkages in the context of Sino-Russian / Soviet rivalry [Электронный ресурс] // Вестник Карагандинского университета. Серия: История. Философия. URL: https://articlekz.com/en/ article/14312 (дата обращения: 10.08.2017).

Stépanoff, Ch. (2009) Chamanisme et transformation sociale à Touva [Электронный ресурс] // Études mongoles et sibériennes, centrasiatiques et tibétaines [En ligne], 35 | 2004, mis en ligne le 17 mars 2009, consulté le 30 septembre 2016. URL: https://emscat.revues.org/487 (дата обращения: 20.08.2017).

Stepanov, V. (2000) Ethnic tensions and separatism in Russia // Journal of Ethnic and Migration Studies. Vol. 26, No. 2. P. 305-332.

Sullivan, S. (1995) Interethnic relations in Post-Soviet Tuva // Ethnic and Racial Studies, Vol. 18. No. 1. P. 64-88.

Tang, P. S. H. (1959) Russian and Soviet Policy in Manchuria and Outer Mongolia. 1911-1931. Durham, NC : Duke University Press. 494 p.

Tannu Tuva 1911-1944 [Электронный ресурс] // The World at War. From Versailles to the Cold War. Website. URL: http://www.schudak.de/timelines/ tannutuva1911-1944.html (дата обращения: 15.08.2017).

The atomic bomb potential of the USSR. July 23, 1951. Document Number (FOIA) / ESDN (CREST): CIA-RDP80-00809A000600400463-3 [Электронный ресурс] // CIA. Freedom of Information Act Electronic Reading Room. URL: https://www.cia.gov/ library/readingroom/docs/CIA-RDP80-00809A000600400463-3.pdf (дата обращения: 21.08.2017).

Tomasic, D. (1950) The Structure of Soviet Power and Expansion // Annals of the American Academy of Political and Social Science. Vol. 271. Moscow's European Satellites. P. 32-42. 
(UNTITLED). August 19, 1946. Document Number (FOIA) / ESDN (CREST): CIA-RDP78-01617A005800030036-3 [Электронный ресурс] // CIA. Freedom of Information Act Electronic Reading Room. URL: https://www.cia.gov/library/ readingroom/docs/CIA-RDP78-01617A005800030036-3.pdf (дата обращения: 20.08.2017).

Varneck, E. (1943), Siberian Native Peoples after the February Revolution // Slavonic and East European Review. American Series. Vol. 2, No. 1. P. 70-88.

Walters, Ph. (2001) Religion in Tuva: Restoration or Innovation? // Religion, State \& Society. Vol. 29, № 1. P. 23-38.

Yakobson, S. (1949) The Soviet Concept of Satellite States // The Review of Politics. Vol. 11, No. 2. P. 184-195.

Дата поступления: 31.08.2017 2.

\section{REFERENCES}

Abaev, N. V. (2006) Nekotorye geopoliticheskie i etnoistoricheskie aspekty "uriankhaiskoi problemy" [Some geopolitical and ethno-historical aspects of the "Uriankhai problem"]. In: Etnosotsial'nye protsessy v Sibiri. Tematicheskii sbornik, issue 7. Novosibirsk, SO RAN. Pp. 201-206. (In Russ.).

Baiyr-ool, M. S. (2014) Khronika vkhozhdeniia Tuvy v sostav SSSR [A chronicle of the accession of Tuva in the USSR]. Tuvinskaia Pravda, 25 September [online] Available at: http://tuvapravda.ru/?q=content/vossoedinenie (access date: 27.07.2017). (In Russ.).

Voskresenskii, A. D. (2004) Kitai i Rossiia v Evrazii. Istoricheskaia dinamika politicheskikh vzaimovliianii [China and Russia in Eurasia. Historical dynamics of political interaction]. Moscow, Muravei. 600 p. (In Russ.).

Galenovich, Iu. M. (1992) «Belye piatna»i «bolevye tochki» $v$ istorii sovetsko-kitaiskikh otnoshenii ["White spots" and "hot buttons" in the history of Soviet-Chinese relations]. Vol. I. Ot Oktiabria 1917 g. do oktiabria 1949 g. [From October 1917 to 1949]. Moscow, Institut Dal'nego Vostoka. 169 p. (In Russ.)

Galenovich, Iu. M. (2008) Dva generalissimusa: I. V. Stalin i Tszian Chzhunchzhen (Chan Kaishi) [Two Generalissimuses: I. V. Stalin and Jiang Zhongzheng (Chiang Kaishek)]. Moscow, IDV RAN. 372 p. (In Russ.).

Gasanly, Dzh. P. (2016) Sin'tszian v orbite sovetskoi politiki: Stalin i musul'manskoe dvizhenie $v$ Vostochnom Turkestane (1931-1949) [Xinjiang in the orbit of the Soviet policy: Stalin and the Muslim movement in East Turkestan (1931-1949)]. Transl. from Azer. by F. Gadzhieva. 2nd ed. Moscow, FLINTA. 360 p. (In Russ.).

Glava III. Vysshie organy gosudarstvennoi vlasti Rossiiskoi Sovetskoi Federativnoi Sotsialisticheskoi Respubliki / Konstitutsiia RSFSR 1937 g. [Chapter III. The Supreme bodies of state power of the Russian Soviet Federative Socialist Republic / the RSFSR 
Constitution of 1937]. Elektronnyi muzei konstitutsionnoi istorii Rossii [online] Available at: http://www.rusconstitution.ru/library/constitution/articles/940/ (access date: 21.08.2017). (In Russ.).

Dokument № 238. Zapis' besedy zaveduiushchego 3-m zapadnym otdelom NKID SSSR A.F. Neimana s vremennym poverennym v delakh SShA v SSSR L. Gendersonom o polozhenii na Dal'nem Vostoke, 14.12.1935 / Sovetsko-amerikanskie otnosheniia. 1934-1939 [Document No. 238. The recording of talks between the Head of the 3rd Western Department of the People's Commissariat of Foreign Affairs, USSR A. F. Neiman, and the chargé d'affaires of the USA in the USSR, L. Henderson, on the situation in the Far East, 14.12.1935 / Soviet-American relations. 1934-1939]. Internet-proekt «Arkhiv Aleksandra N. Iakovleva» [online] Available at: http://www. alexanderyakovlev.org/fond/issues-doc/70521 (access date: 27.07.2017). (In Russ.).

Dokumenty vneshnei politiki. 22 iiunia 1941 - 1 ianvaria 1942 [Documents of foreign policy. 22 June 1941 - 1 January 1942] (2000). Moscow, Mezhdunarodnye otnosheniia. Vol. XXIV. 632 p. (In Russ.).

Istoriia Tuvy [The History of Tuva] (2007). Novosibirsk, Nauka. Vol. II. 430 p. (In Russ.).

Kan, V. S. (2015) Etapy stanovleniia i razvitiia periodicheskoi pechati Tuvy (19241985) [The stages of formation and development of periodical press in Tuva (19241985)]. Vestnik Omskogo universiteta, no. 2, pp. 121-125. (In Russ.).

Kapitsa, M. S. (1996) Na raznykh paralleliakh. Zapiski diplomata [On different Parallels. Notes of a diplomat]. Moscow, Kniga i biznes. 480 p. (In Russ.).

Komarova, V. V. (2014) Narodnye golosovaniia v Rossiiskoi Federatsii [Popular vote in the Russian Federation]. Moscow, Directmedia. 477 p. (In Russ.).

Konstitutsiia SSSR 1936 goda [The USSR Constitution of 1936]. Elektronnyi muzei konstitutsionnoi istorii Rossii [online] Available at: http://www.rusconstitution.ru/ library/constitution/articles/1223/ (access date: 21.08.2017). (In Russ.).

Konstitutsiia SSSR v redaktsii ot 7 oktiabria $1977 \mathrm{~g}$. [The Constitution of the Soviet Union as amended on October 7, 1977]. Elektronnyi muzei konstitutsionnoi istorii Rossii [online] Available at: http://www.rusconstitution.ru/library/constitution/ articles/9681/ (access date: 21.08.2017). (In Russ.).

Luzianin, S. G. (2003) Rossiia - Mongoliia - Kitai v pervoi polovine XX veka. Politicheskie vzaimootnosheniia v 1911-1946 gg. [Russia - Mongolia - China in the first half of the twentieth century. Political relations in 1911-1946]. Moscow, OGNI. 320 p. (In Russ.).

Moskalenko, N. P. (2004) Etnopoliticheskaia istoriia Tuvy $v$ XX veke [Ethnopolitical history of Tuva in the 20th century]. Moscow, Nauka. 222 p. (In Russ.).

Obukhov, V. G. (2012) Poteriannoe Belovod'e. Istoriia Russkogo Sin'tsziana [The Lost Belovodye. The story of the Russian Xinjiang]. Moscow, ZAO Izdatel'stvo Tsentrpoligraf. 676 p. (In Russ.). 
Otroshchenko, I. V. (2010) “...Vin zhive tsieiu ideeiu”: panmongol's'kii vektor Kh. Choibalsana [“...He lives by this idea”: a pan-Mongolian vector of Kh. Choibalsan]. Shìdnij svìt, no. 3, pp. 81-91. (In Ukr.).

Otroshchenko, I. V. (2011) Na shliakhu do Velikoï Mongolii (panmongol's'kii rukh u 1920-1930-ti roki) [On the way to Great Mongolia (pan-Mongolian movement in 1920s-1930s)]. Kyiv. 456 p. (In Ukr.).

Protokoly 1-go Velikogo Huraldana Mongol'skoj Narodnoj Respubliki [The protocols of the 1st Great Huraldan of the Mongolian People's Republic] (1925) Ulaanbaatar. 276 p. (In Russ.).

Roshchin, S. K. (2005) Marshal Mongolii Kh. Choibalsan. Shtrikhi biografii [The Marshal of Mongolia Kh. Choibalsan. Notes towards a biography]. Moscow, IV RAN. 158 p. (In Russ.).

Saaia, S. V. and Sat, S. Ch. (2006) Geopoliticheskii status Tuvy v pervoi polovine XX veka (1911-1944 gody) [Geopolitical status of Tuva in the first half of the twentieth century (1911-1944)]. Abakan, Khakasskoe kn. izd-vo. 293 p. (In Russ.).

Sbornik zakonov $i$ osnovnykh postanovlenii Pravitel'stva Tuvinskoi Narodnoi Respubliki [A collection of laws and fundamental orders of the government of Tuvan People's Republic] (1944). Kh. Anchima and S. T. Chimba (Eds.). Kyzyl, Tuvinskoe gosudarstvennoe izdatel'stvo. 456 p. (In Russ.).

Sobranie arkhivnykh dokumentov o protektorate Rossii nad Uriankhaiskim kraemTuvoi: $k$ 100-letiiu istoricheskogo sobytiia [A collection of archival documents on Russian protectorate over Uriankhai Krai - Tuva: the 100th anniversary of the historical event] (2014). Compl.: T. A. Bondarenko and all. Kyzyl, TIGI, 479 p. (In Russ.).

Sobranie arkhivnykh dokumentov po istorii Tuvy [A collection of archival documents on the history of Tuva] (2014) : in 4 vols. Ulaanbaatar; Kyzyl, ADMON PRINT. Vol. III. 1921-1944 gg. 418 p. (In Mong., Tuvin., Russ.).

Sovetskoe rukovodstvo. Perepiska. 1928-1941 gg. [Soviet leadership. Correspondence. 1928-1941] (1999). Moscow, Rossiiskaia politicheskaia entsiklopediia. 519 p. (In Russ.).

Schimmelpennink van der Oye, D. (1997) Neizvestnyi Przheval'skii [Unknown Przewalski]. Ariavarta, scientific journal, no. 1, pp. 207-226. (In Russ.).

Syroezhkin, K. L. (2003) Mify i real'nost' etnicheskogo separatizma $v$ Kitae $i$ bezopasnost' Tsentral'noi Azii [Myths and realities of ethnic separatism in China and the security of Central Asia]. Almaty, Daik-Press. 736 p. (In Russ.).

Tuguzhekova, V. N. (2016) Khakassko-altaiskie vzaimootnosheniia (vtoraia polovina XVII - nachalo XX v.) [Khakas-Altai, the relationship (second half of XVII - beginning of XX century)]. In: Altai - Rossiia: cherez veka $v$ budushchee : materialy Vserossiiskoi nauchno-prakticheskoi konferentsii s mezhdunarodnym uchastiem, posviashchennoi 260-letiiu dobrovol'nogo vkhozhdeniia altaiskogo naroda $v$ sostav Rossiiskogo gosudarstva i 25-letiiu obrazovaniia Respubliki Altai [Altai-Russia: through the centuries to the future: 
Proceedings of all-Russian research conference with international participation dedicated to the 260th anniversary of the voluntary entry of the Altai people into the Russian state and the 25th anniversary of declaration of the Altai Republic] / ed. by V. G. Babin. GornoAltaisk, RIO Gaga. 444 p. Pp. 20-23. (In Russ.).

Tiukhteneva, S. P. (2006) Istoricheskie i etnogeneticheskie sviazi mongolov i altaitsev ili Chingiskhan vozvrashchaetsia [Historical and ethno-genetic relations of Mongols and Altaians, or the comeback of Genghis Khan]. In: IX Mezhdunarodnyi kongress mongolovedov (Ulan-Bator, 8-12 avgusta 2006 g.). Doklady rossiiskikh uchenykh [IX international Congress of Mongolian studies (Ulan Bator, August 8-12, 2006). Papers of Russian scholars]. Moscow, IV RAN. Pp. 163-168. (In Russ.)

Kharunova, M. M. (2011) Sotsial'no-politicheskoe razvitie Tuvy v seredine XX veka [Sociopolitical development of Tuva in the mid-twentieth century]. Novosibirsk, Nauka. 135 p. (In Russ.).

Khomushku, Iu. Ch. (2002) Protsessy sblizheniia i vkhozhdeniia Tuvinskoi Narodnoi Respubliki $v$ sostav SSSR: 20-40-e gody XX v. [Process of rapprochement and accession of the Tuvan People's Republic in the USSR: 1920s-1940s]: Thesis of Diss.... Candidate of History. Moscow. 18 p. (In Russ.).

Shinkarev, L. I. (2006) Tsedenbal i ego vremia [Tsedenbal and his time] : in 2 vols. Moscow, Sobranie. Vol. 1: Liubov'. Vlast'. Tragediia [Love. Power. Tragedy]. 496 p. (In Russ.).

Academy of Science's Role in Field Expeditions. December 29, 1949. Document Number (FOIA) / ESDN (CREST): CIA-RDP80-00926A001800040002-8. CIA. Freedom of Information Act Electronic Reading Room [online] Available at: https://www.cia.gov/ library/readingroom/docs/CIA-RDP80-00926A001800040002-8.pdf (access date: 27.08.2017).

Alatalu, T. (1992) Tuva. A State Reawakens. Soviet Studies, vol. 44, no. 5, pp. 881-895.

Alatalu, T. and Strupp, M. (2012) Tuva. Max Planck Encyclopedia of Public International Law [MPEPIL], vol. 10. Oxford, Oxford University Press. Pp. 124-127.

Alatalu, T. (2013) Geopolitics Taking the Signature from the Russian-Estonian Border Treaty (2005). Baltic Journal of European Studies Tallinn University of Technology, vol. 3, no. 2 (14), pp. 96-119.

Atwood, C. P. (2004) Encyclopedia of Mongolia and the Mongol empire. New York, Facts on File. 678 p.

Ballis, W. B. (1956) The Political Evolution of a Soviet Satellite: The Mongolian People's Republic. The Western Political Quarterly, vol. 9, no. 2, pp. 293-328.

Batbayar Ts. (1996) Modern Mongolia a concise History. Ulaanbaatar. 127 p.

Christopher, A. J. (2001) State failure in the twentieth century. Geographica Slovenica, no. 34, pp. 49-63.

Dashpurev, D. and Usha, P. (1993) Mongolia: Revolution and Independence. 19111992. New Delhi, Subhash. 148 p. 
Eismont, M. (1996) Tuva: Rejoining the Fold. Transl. by M. Eckert. Prism, vol. 2, issue 18 [online] Available at: https://jamestown.org/program/tuva-rejoining-thefold/ (access date: 12.08.2017).

Endicott, E. (1999) Russian Merchants in Mongolia: The 1910 Moscow Trade Expedition. Mongolia in the Twentieth Century: Landlocked Cosmopolitan. New York, L., M. E. Sharpe. Pp. 59-68.

Fisher, H.H. (1949). Soviet Policies in Asia. Annals of the American Academy of Political and Social Science, vol. 263: The Soviet Union Since World War II. Pp. 188-201.

Fondahl, G. A. (1995) Siberia's First Nations. The National Council for Soviet and East European Research. Washington. 39 p.

Foreign Relations of the United States: Diplomatic Papers, 1935. Vol. III: The Far East. J. G. Reid, L. E. Gates and R. R. Goodwin (Eds.). Washington, Government Printing Office, $1953.868 \mathrm{p}$.

Foreign Relations of the United States: Diplomatic Papers. The Conferences at Cairo and Tehran, 1943 (1961). W. M. Franklin and W. Gerber (Eds.). Washington, Government Printing Office. $932 \mathrm{p}$.

Foreign Relations of the United States: Diplomatic Papers. The Conference of Berlin (The Potsdam Conference), 1945 (1960) Vol. II. Richardson D. (Ed). Washington, Government Printing Office.

Foreign Relations of the United States, 1946, The Far East: China (1972) Vol. X. R. R. Goodwin, H. A. Fine, F. C. Prescott and V. H. Cassidy (Eds.). Washington, Government Printing Office.

Forsyth, J. (2000) A History of the Peoples of Siberia: Russia's North Asian Colony 1581-1990. Cambridge, UK, Cambridge University Press. 476 p.

Grajdanzev, A. J. (1945) Soviet Position in the Far East. Far Eastern Survey, vol. 14, no. 23, pp. 334-337.

Hagendoorn, L., Poppe, E. and Minescu, A. (2008). Support for Separatism in Ethnic Republics of the Russian Federation. Europe-Asia Studies, vol. 60, no. 3, pp. 353-373.

Harrison, K. D. Naming Practices and Ethnic Identity in Tuva. Swarthmore College [online] Available at: http://citeseerx.ist.psu.edu/viewdoc/download?doi=10.1.1.506. 6971\&rep=rep1\&type=pdf (access date: 29.07.2017).

Heaton, W. (1973) Mongolia: Troubled Satellite. Asian Survey, vol. 13, no. 2, pp. 246-251.

Henze, P. B. (1994) Ethnic Dynamics and Dilemmas of the Russian Republic. Studies in Conflict \& Terrorism, vol. 17, issue 1, pp. 61-86.

Information on Soviet military strength. 17 July 1950. Document Number (FOIA) / ESDN (CREST): CIA-RDP82-00039R000100070017-6. CIA. Freedom of Information Act Electronic Reading Room [online] Available at: https://www.cia.gov/ library/readingroom/docs/CIA-RDP82-00039R000100070017-6.pdf (access date: 25.08.2017). 
Khertek Anchimaa-Toka. Revolvy [online] Available at: https:/www.revolvy.com/ main/index.php?s=Khertek\%20Anchimaa-Toka\&item_type=topic (access date: 25.08.2017).

Kolarz, W. (1954) The Peoples of the Soviet Far East. New York, Parager. 193 p.

Körner-Lakatos, E. (2010) Ada Kaleh, Tannu-Tuwa, Acre. Fünfzig historische Nischen. Monsenstein und Vannerdat, Münster.

Kuei-hsiang Hsu (2007) The Relationship between the Republic of Tuva and the Russian Federal Government since the 1990s. Bimonthly Journal on Mongolian and Tibetan Current Situation, vol. 17, no. 1, pp. 1-22.

Lattimore, O. (1930) Political Conditions in Mongolia and Chinese Turkestan. Annals of the American Academy of Political and Social Science, vol. 152, pp. 318-327.

Lattimore, O. (1946) The Outer Mongolian Horizon. Foreign Affairs, vol. 24, no. 4, pp. 648-660.

Lattimore, O. (1962) Nomads and Commissars. Mongolia Revisited. New York, Oxford University Press. 238 p.

Mansvetov, F. S. (1947) Tannu-Tuva - The Soviet «Atom City»? Russian Review, vol. 6, no. 2, pp. 9-19.

McMullen, R. Tuva: Russia's Tibet or the Next Lithuania? Friends of Tuva [online] Available at: http://www.fotuva.org/misc/mcmullen.html (access date: 20.08.2017).

Minahan, J. (2004) The former Soviet Union's diverse peoples: a reference sourcebook. Santa Barbara, Calif. [u.a.], ABC-Clio. 389 p.

Minahan, J. (2014) Ethnic Groups of North, East, and Central Asia: An Encyclopedia. Santa Barbara, Calif., ABC-Clio. 345 p.

Mongush, M. (1993) The annexation of Tannu-Tuva and the formation of the Tuvinskaya ASSR. Nationalities Papers: The Journal of Nationalism and Ethnicity, vol. XXI, no. 2, pp. 47-52.

Narangoa, Li and Cribb, R. (2014) Historical atlas of northeast Asia, 1590-2010: Korea, Manchuria, Mongolia, Eastern Siberia. New York, Columbia University Press. $352 \mathrm{p}$.

Paine, S. C. M. (1996) Imperial Rivals: China, Russia, and Their Disputed Frontier. M. E. Sharpe. 417 p.

Rieber, A. J. (2015) Stalin and the Struggle for Supremacy in Eurasia. Cambridge University Press. 429 p.

Rojo, M., Chondan, R. M., Chondan, Ch. S. and Lavrillier, A. (2016) «Adaptation des rites «traditionnels» chez les Touvas de Kyzyl de la période soviétiqueà l'urbanisation». Études mongoles et sibériennes, centrasiatiques et tibétaines, 47 [online] Available at: http://emscat.revues.org/2856 (access date: 20.08.2017).

Rupen, R. (1966) The Mongolian People's Republic. Stanford, Calif., Hoover Institution on War, Revolution, and Peace, Stanford University. 74 p. 
Rupen, R. A. (1973). The Fiftieth Anniversary of the Mongolian People's Republic: 1921-1971. Asian Survey, vol. 13, no. 5, pp. 458-469.

Rupen, R. A. (1975) The absorption of Tuva. In: T. T. Hammond (Ed.) The Anatomy of Communist Takeovers. New Haven, Yale University Press. Pp. 148-150.

Somuncuoğlu, A. (2002) Tuva (Tiva) Cumhuriyeti. In: Türkler. Vol. 20. Türk dünyası. Yeni Türkiye Yayınları. Ankara. Pp. 275-295. (In Turk.).

Soni, S. K. (2009) Exploring the history of Tuva-Mongolia linkages in the context of Sino-Russian / Soviet rivalry. Vestnik Karagandinskogo universiteta. Seriia: Istoriia. Filosofiia [online] Available at: https://articlekz.com/en/article/14312 (access date: 10.08.2017).

Stépanoff, Ch. (2009) Chamanisme et transformation sociale à Touva. Études mongoles et sibériennes, centrasiatiques et tibétaines, 35 [online] Available at: https:// emscat.revues.org/487 (access date: 20.08.2017).

Stepanov, V. (2000) Ethnic tensions and separatism in Russia. Journal of Ethnic and Migration Studies, vol. 26, no. 2, pp. 305-332.

Sullivan, S. (1995) Interethnic relations in Post-Soviet Tuva. Ethnic and Racial Studies, vol. 18, no.1, pp. 64-88.

Tang, P. S. H. (1959) Russian and Soviet Policy in Manchuria and Outer Mongolia. 1911-1931. Durham, NC, Duke University Press. 494 p.

Tannu Tuva 1911-1944. The World at War [online] Available at: http://www. schudak.de/timelines/tannutuva1911-1944.html (access date: 15.08.2017).

The atomic bomb potential of the USSR. July 23, 1951. Document Number (FOIA) / ESDN (CREST): CIA-RDP80-00809A000600400463-3. CIA. Freedom of Information Act Electronic Reading Room [online] Available at: https://www.cia.gov/ library/readingroom/docs/CIA-RDP80-00809A000600400463-3.pdf (access date: 21.08.2017).

Tomasic, D. (1950). The Structure of Soviet Power and Expansion. Annals of the American Academy of Political and Social Science, vol. 271. Moscow's European Satellites. Pp. 32-42.

(UNTITLED). August 19, 1946. Document Number (FOIA) / ESDN (CREST): CIARDP78-01617A005800030036-3. CIA. Freedom of Information Act Electronic Reading Room [online] Available at: https://www.cia.gov/library/readingroom/docs/CIARDP78-01617A005800030036-3.pdf (access date: 20.08.2017).

Varneck, E. (1943) Siberian Native Peoples after the February Revolution. Slavonic and East European Review. American Series, vol. 2, no. 1, pp. 70-88.

Walters, Ph. (2001) Religion in Tuva: Restoration or Innovation? Religion, State \& Society, vol. 29, no. 1, pp. 23-28.

Yakobson, S. (1949) The Soviet Concept of Satellite States. The Review of Politics, vol. 11, no. 2, pp. 184-195. 


\section{Для цитирования:}

Отрощенко И. В. Вхождение Тувы в состав СССР: альтернативные мнения [Электронный ресурс] // Новые исследования Тувы. 2017, № 4. URL: https://nit.tuva.asia/nit/ article/view/738 (дата обращения: дд.мм.гг.). DOI: 10.25178/nit.2017.4.3

\section{For citation:}

Otroshchenko I. V. Tuva's Accession to the USSR: Alternative opinions. The New Research of Tuva, 2017, no. 4 [on-line] Available at: https://nit.tuva.asia/nit/article/view/738 (accessed: ... ). DOI: 10.25178/nit.2017.4.3 